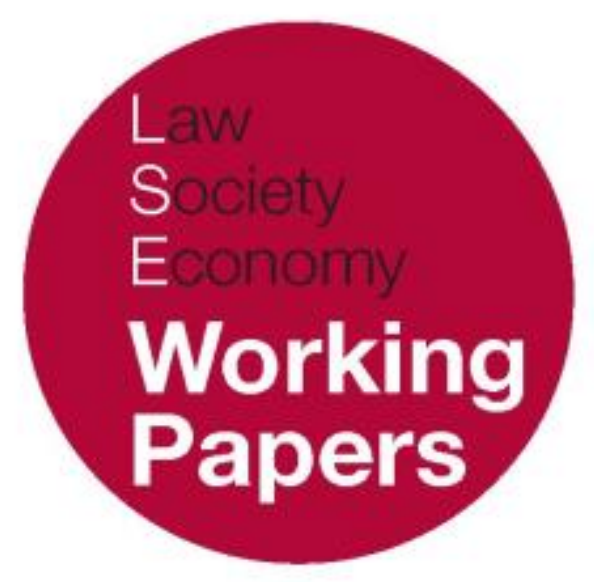

\title{
Price Regulation in the Social Market Economy
}

\section{Niamh Dunne}

LSE Law, Society and Economy Working Papers 3/2017

London School of Economics and Political Science

Law Department

This paper can be downloaded without charge from LSE Law, Society and Economy Working Papers at: www.lse.ac.uk/collections/law/wps/wps.htm and the Social Sciences Research Network electronic library at: https://papers.ssrn.com/sol3/papers.cfm?abstract_id=2921037. (C) Niamh Dunne. Users may download and/or print one copy to facilitate their private study or for non-commercial research. Users may not engage in further distribution of this material or use it for any profit-making activities or any other form of commercial gain. 


\title{
Price Regulation in the Social Market Economy
}

\author{
Niamh Dunne *
}

\begin{abstract}
Establishing open and undistorted competition within the internal market is a primary goal of the EU legal framework. Price controls, by contrast, are among the clearest derogations from this overarching objective. Yet much price regulation continues to occur within the internal market. The treatment of such regulation thus raises challenging questions, both substantive and institutional, about the nature of economic governance in the context of the EU's 'highly competitive social market economy'. This article begins with a consideration of price regulation, both in economic terms and in relation to its place within the institutional and ideological structure of the EU. It then examines differing approaches seen in EU law: from a sceptical prohibitive approach, to a cautious yet more receptive permissive approach, to an essentially prescriptive approach incorporating price regulation into the fabric of the internal market. The aim is to contribute to a more nuanced understanding of the challenges facing the pursuit of 'open and undistorted competition' within a modern social market economy.
\end{abstract}

\footnotetext{
* Assistant Professor, Department of Law, London School of Economics and Political Science. Grateful thanks to Floris de Witte for his helpful comments. Portions of this material were presented in an earlier format at the fourth Next Generation of Antitrust Scholars Conference at NYU School of Law in January 2016; further thanks are due to participants and Pablo Ibáñez Colomo for comments on that work. Errors remain my own.
} 


\section{INTRODUCTION}

Establishing open and undistorted competition within the internal market is a primary goal of the European Union (EU) legal framework. ${ }^{1}$ In developing a 'highly competitive social market economy,'2 interventions focus on prevention and proscription of anticompetitive practices by Member States and individual undertakings, alongside harmonised efforts at wider sector liberalisation. Price controls, acknowledged as 'one of the most intrusive forms of intervention in the market,' ${ }^{3}$ are among the most 'extreme'4 derogations from this objective. Price is one of, if not the, foremost dimensions of competition: 5 indeed, 'competition is, by its very essence, determined by price'. ${ }^{6}$ Yet, both because the competitive process is often imperfect, and because social considerations may override competitive ones within the wider context of the EU's market economy, price regulation is not irreconcilable, a priori, with the goals and strictures of EU law. This article considers the treatment of price regulation in this context-located at the intersection of competition policy, social policy, and market integration-, exploring the implications of the balance that is struck within the EU's so-called 'economic constitution'.?

The dilemma of price regulation is located at the confluence of two distinct yet related tensions: a regulatory friction and a sovereignty-based one. First, the task of price regulation is a much-disputed enterprise in contemporary regulatory practice. Price controls are criticised as costly, unnecessary, liable to abuse, and ultimately counterproductive. Yet the pragmatic recognition that unrestrained competition does not guarantee efficient or otherwise socially desirable outcomes means that the 'second best' solution of regulation may indeed be optimal in certain circumstances. Effective controls require a close understanding of the relevant market, however, which links to our second source of friction, namely the sharing of regulatory jurisdiction between the EU and its Member States. The necessity and optimal scope of price controls may be most apparent at the domestic level; yet differentiated regulation risks fragmentation, competitive distortions, and furtherance of domestic interests at the expense of integration. The approach of EU law must accommodate these tensions, arising both from the ambiguous virtues of price regulation as such and from the multilevel nature of regulatory policymaking within the EU.

Price controls are a comparatively 'old-fashioned' instrument of regulation, and thus, arguably, a case must be made for the contemporary relevance of the

\footnotetext{
${ }^{1}$ In addition to the substantive competition rules in Articles 101-109 of the Treaty on the Functioning of the European Union (TFEU), see, e.g., references to avoiding distortions of competition in Articles 32(c), 113, 116 and 348 TFEU, alongside 'the principle of an open market economy with free competition' in Articles 119, 120 and 127 TFEU.

2 Article 3(3), Treaty on European Union (TEU).

3 Opinion of Advocate General Poiares Maduro in Case C-58/08 Vodafone EU:C:2009:596, para.38.

4 Opinion in Vodafone, para.42.

5 See, e.g., Commission Decision of 9 November 2010 in Case AT.39258 — Airfreight, para.900: 'Price being the main instrument of competition...'.

${ }^{6}$ Opinion of Advocate General Szpunar in Case C-148/15 Deutsche Parkinson Vereinigung eV ventrale zur Bekämpfung unlauteren Wettbewerbs eV EU:C:2016:394, para.18.

7 Opinion in Deutsche Parkinson, para.1.
} 
topic. Reflecting perhaps an historical fondness for such intervention within many European countries, ${ }^{8}$ there is first the fact that considerable price regulation continues to occur within the internal market today. Thus, at a wholly practical level, the topic retains importance, even if economic purists might wish this were not the case. The treatment of price controls under EU law furthermore raises exceptional issues in the context of both negative 9 and positive ${ }^{10}$ integration efforts, yet the existing literature is under-developed in terms of exploring what is so special about regulating price. In suggesting a tripartite balancing of competitive, integrationist and social concerns, this article adopts a transversal approach, which endeavours to identify and analyse the treatment of analogous regulatory phenomena across differing elements of the EU system, while drawing links between existing scholarship in the fields of EU law and competition policy. At its most ambitious, the aim is to contribute to a more nuanced understanding of what is meant by 'open and undistorted competition' within the internal market, alongside the challenges facing its pursuit in a modern social market economy.

The article is structured as follows. Sections II and III consider price regulation generally, addressing its treatment in economic terms and its place within the institutional and ideological structure of the EU, respectively. The article then examines differing approaches under EU law: from a sceptical probibitive approach (section IV), to a cautious yet more receptive permissive approach (section V), to an essentially prescriptive approach incorporating price regulation into the fabric of the internal market (section VI). Across these diverse strands, EU law grapples both with substantive concerns-the question of when price regulation might be a proportionate and permissible solution within the internal market-and institutional ones-questions of when and how the EU institutions might intervene to guide or even override domestic regulators. Section VII concludes briefly.

\section{THE MECHANICS OF PRICE REGULATION}

We start by considering what price regulation entails, and why it is disfavoured in contemporary policymaking. Within neoclassical economics, ${ }^{11}$ the free operation of the price formation mechanism is vital to the effective and efficient functioning of competitive markets. There is, therefore, a default assumption that price should

\footnotetext{
8 See e.g. Gerber, Law and Competition in Twentieth Century Europe, OUP (1998).

${ }_{9}$ Discussing the atypical treatment of price regulation in the context of the free movement provisions, see e.g. Barnard, The Substantive Law of the EU: The Four Freedoms, OUP (2016), 87; Alemmano, "Balancing Free Movement and Public Health: The Case of Minimum Unit Pricing of Alcohol in Scotch Whiskyy," 53 CMLRev 1037 (2016), 1047-51; and Opinion of Advocate General Bot in Case C-333/14 Scotch Whisky Association and Others $v$ The Lord Advocate and The Advocate General for Scotland EU:C:2015:527, fn.53.

${ }_{10}$ Several of the most important cases considering the principle of subsidiarity, for instance, concern EUlevel efforts to control or implement price regulation: see Cases C-58/08 The Queen, on the application of Vodafone Ltd and Others $v$ Secretary of State for Business, Enterprise and Regulatory Reform EU:C:2010:321 and C176/09 Commission v Luxembourg EU:C:2011:290.

11 Authoritative accounts include Mankiw \& Taylor, Economics (3 ${ }^{\text {rd }}$ ed.), Thomson Learning, London (2014), particularly chpt.3.
} 
be determined, principally, by interaction of levels of supply (producers/service providers) and demand (consumers) in a market. Assuming a degree of substitutability between products or services, price is the most immediate parameter upon which undertakings compete. Beyond this, the price formation process generates signalling effects which facilitate efficient behaviour. High prices suggest that demand outstrips supply, which indicates that a market is profitable and invites entry-which, other things being equal, should lower prices due to increased competition. Concomitantly, high prices force consumers to reflect upon the extent to which they value a good or service and, in theory, result in that scarce commodity being allocated to those who value it the greatest. In this manner, the price formation mechanism leads to an efficient distribution of society's finite resources.

The textbook understanding of market-clearing relies, however, upon several assumptions which may not hold true. High prices cannot lead to greater competition if there are barriers to entering a market, meaning that new entrants are dissuaded or delayed, and supra-competitive pricing and scarcity is prolonged. Equally, barriers to exit may prolong over-supply and wastage. Moreover, rational consumer behaviour is premised upon complete information-not always a given, particularly where the product or service is complex-; an ability to switch or do without in response to price-gouging - again, not always possible, particularly in the context of necessary goods, such as electricity-; and an absence of externalities, meaning broader consequences beyond the circumstances of the transaction. Where private price formation delivers a sub-optimal result, there is an argument for public pre-emption.

Price regulation refers to regulatory methods of determining and imposing controls on firms or industries. ${ }^{12}$ 'Regulatory,' here, implies a degree of public involvement in the price formation process. The immediate objective of most price regulation is, self-evidently, to constrain independent price-setting; in effect, to prevent regulated firms from charging higher-or, more unusually, lowerprices for products or services. This may involve a fixed price or rate of return; a maximum price ceiling or minimum price floor; or more oblique forms of regulation such as a prohibition on practices like below-cost sales.

Price controls are most frequently imposed in markets with natural monopoly or oligopoly components without free entry, where the undertaking(s) concerned are likely, absent intervention, to set prices near monopoly level. ${ }^{13}$ In such circumstances, the rationale for regulation is, typically, to prevent consumer exploitation through excessive retail prices, or to avoid market foreclosure, where high wholesale prices might obstruct downstream competition. As the examples below illustrate, however, price regulation has been considered necessary to further a broader range of regulatory objectives beyond the realms of competition policy, including social concerns-for example, where prices for consumer essentials are maintained at lower levels, or for harmful goods at elevated levels-; or, more contentiously, to 'stabilise' ostensibly excessive competition. Price regulation thus may play a redistributive role, by preventing transfer of (arguably

${ }^{12}$ See, generally, Baldwin, Cave \& Lodge, Understanding Regulation, 2nd ed., OUP (2011), chpts.22 and 25.

${ }^{13}$ Motta, Competition Policy: Theory and Practice, CUP, Cambridge (2004), 25. 
unfair levels of) wealth from consumers to producers. Moreover, price regulation is often inextricably linked to other regulatory controls, including access or quality requirements.

Despite the acknowledged weaknesses within price formation processes, price controls are, however, the exception rather than the rule in contemporary practice. ${ }^{14}$ Hostility arises on multiple fronts. Determination of any regulated price is a complex task..$^{15}$ Regulators must ensure that regulated entities retain incentives to operate efficiently, while ensuring that profits are neither excessive nor unviable. Price controls can have unintended negative consequences, such as rentseeking, moral hazard, inefficient subsidies, or distortion of optimal supply and demand levels ${ }^{16}$ or regulatory lag may arise, whereby delays in responding to new market conditions render the regulated price increasingly inappropriate. ${ }^{17}$ Indiscriminate application of pricing controls might furthermore damage corporate incentives to invest, thus leading to a diminution in innovation and a reduction in overall consumer welfare. ${ }^{18}$

More broadly, the provocative public choice literature launched a fundamental attack on regulation as an inherently flawed or even corrupt enterprise that benefits only the regulated at the expense of broader public interest. ${ }^{19}$ Although overstating the risk of capture, ${ }^{20}$ public choice was influential, alongside more measured critiques that consider the potential costs and inefficiency of regulation, ${ }^{21}$ in provoking efforts towards deregulation and regulatory reform. Specifically, there has been a movement away from prescriptive forms of 'command-and-control' regulation, including price controls, to alternatives such as incentive-based regulation, market-harnessing controls, ${ }^{22}$ and 'nudge' strategies. ${ }^{23}$ In its own practice, the EU emphasises 'better regulation'24 and, increasingly, 'smart regulation,' defined as regulation 'of the highest quality possible.' 25

\footnotetext{
${ }^{14}$ In most economies, price controls exist only within public utility sectors, such as energy, telecommunications or transport: Baldwin et al. (2011), 443.

${ }^{15}$ See, generally, Viscusi, Harrington \& Vernon, Economics of Regulation and Antitrust, $4^{\text {th }}$ ed. MIT Press, Cambridge MA (2005).

16 Viscusi et al. (2005), 663-69.

17 Ibid, 358.

${ }^{18}$ Baldwin et al. (2011), 476.

${ }^{19}$ See, e.g., Stigler, 'The Theory of Economic Regulation,' 2(1) The Bell Journal of Economics and Management Science 3-21 (1971).

${ }^{20}$ See, e.g., Posner, 'The Concept of Regulatory Capture: A Short, Inglorious History' in Carpenter \& Moss (eds.), Preventing Regulatory Capture, CUP (2014).

${ }^{21}$ See, e.g., Breyer, Regulation and its Reform, Harvard University Press, Cambridge MA, (1982).

22 See, e.g., the EU's emissions trading scheme: Directive 2003/87/EC of 13 October 2003 establishing a

scheme for greenhouse gas emission allowance trading within the Community and amending Council

Directive 96/61/EC (OJ L 275/32, 25.10.2003).

${ }^{23}$ Baldwin et al. (2011), 110-133.

${ }^{24}$ European Commission, Updating and Simplifying the Community Acquis (COM(2003) 71 final), published 2

February 2003.

${ }^{25}$ European Commission, Smart Regulation in the European Union (COM(2010)543 final), published 8

October 2010, 3 .
} 


\section{PRICE REGULATION AND THE LEGAL FRAMEWORK OF THE EUROPEAN UNION}

Beyond these general critiques, price regulation poses specific difficulties-both ideological and practical —within the framework of the internal market. While not prohibited a priori, the application of price controls is an almost contradictory exercise within the broader EU context, including pursuit of a competitive internal market and the underlying constitutional structure. A core focus of this article is to explore how these tensions are manifested and accommodated-to a greater or lesser extent—within this legal framework.

EU law interacts with and regulates price-setting on three distinct levels. ${ }^{26}$ It, first, constrains the ability of individual undertakings to set prices, under competition law. Second, it limits the ability of Member States to engage in domestic regulation, particularly under the free movement rules. It is at this juncture that the constituent elements of the social market economy are most vulnerable to discordance. ${ }^{27}$ An example is Scotch Whisky, where national efforts to impose a minimum retail price per unit of alcohol, motivated by public health concerns about hazardous drinking, conflicted with Article 34 TFEU insofar as the domestic regulation hindered access to the Scottish market. ${ }^{28}$ Third, and most exceptionally, there is scope for direct implementation of price controls as a matter of EU law. A prominent example is the Roaming Regulation, which capped and progressively reduced prices for mobile phone consumers who use their devices abroad. ${ }^{29}$ This article focuses on the latter two dimensions, namely national and EU-level regulatory efforts. Both involve a top-down centralised determination of ostensible market outcomes, albeit regulatory policymaking occurs at differing levels within the complex EU structure. In making this distinction, it is necessary to explain briefly why competition law lies outside the framework governing price regulation as such.

A central concern of competition law is to avoid or control aggregations of market power that, ultimately, enable undertakings to raise prices to supracompetitive levels. ${ }^{30}$ At first glance, moreover, antitrust enforcement against specific prices — high or low-provides a broadly equivalent means to exert public control over pricing by private actors. Article 101 TFEU prohibits certain coordinated price-setting, particularly between horizontal competitors, ${ }^{31}$ while

\footnotetext{
26 Opinion in Vodafone, para.1.

27 An illuminative discussion of the inherent and longstanding tensions between the 'social' and 'market' components of the internal market is found in de Witte, "The Architecture of the EU's Social Market Economy" in Koutrakos \& Snell, Research Handbook on the Law of the EU's Internal Market, Edward Elgar Publishing, Cheltenham (2017).

${ }^{28}$ Case C-333/14 Scotch Whisky Association and Others $v$ The Lord Advocate and The Advocate General for Scotland EU:C:2015:845.

${ }^{29}$ Regulation $717 / 2007$ of 27 June 2007 on roaming on public mobile telephone networks within the Community and amending Directive 2002/21/EC (OJ L171/32, 29.6.2007) ('Roaming Regulation').

30 See e.g. European Commission, Guidance on the Commission's enforcement priorities in applying Article 82 of the EC Treaty to abusive exclusionary conduct by dominant undertakings (OJ C 45/7, 24.2.2009), para.19, and Case T472/13 Lundbeck EU:T:2016:449, para.386.

31 Although price-fixing cartels provide the clearest example of anticompetitive coordination, Article 101 TFEU addresses certain non-cartel horizontal activity (e.g. C-382/12 P MasterCard EU:C:2014:2201) and vertical practices (e.g. C-161/84 Pronuptia de Paris GmbH EU:C:1986:41).
} 
Article 102 TFEU targets abusive pricing practices by dominant undertakings. ${ }^{32}$ More unusually, pricing commitments in merger control proceedings may result, obliquely, in de facto regulation. ${ }^{33}$ If coupled with sufficiently prescriptive remedial structures, competition law may achieve a broadly similar outcome to direct regulation, albeit in a less comprehensive manner.

Yet, ad hoc intervention against individual pricing is substantially different to the regulatory task of implementing and enforcing price controls, both conceptually and practically. Outside the merger context, antitrust enforcement is an essentially reactive enterprise, constraining freedom to set prices only to the extent that such activity violates the discrete prohibitions of Articles 101 and 102. Price regulation, as understood here, involves instead the systematic, proactive overreaching of the market mechanism and enterprise freedom. ${ }^{34}$ Contemporary competition law is also notably poor at remedying, or largely indifferent to, the sorts of market failures that prompt price controls. Enforcers in the EU, as elsewhere, are less concerned with specific prices than with the structure and functioning of markets. In most cases where pricing is challenged, the core concern is not the price itself, but its broader context or impact. ${ }^{35}$ Although Article 102 proscribes discriminatory ${ }^{36}$ and excessive pricing, ${ }^{37}$ such theories of harm are disfavoured and under-utilised. ${ }^{38}$ Price controls may also pursue noneconomic objectives outside the realm of competition policy. More fundamentally, the fact that an intensive on-going remedy like price regulation is deemed necessary may imply structural problems that cannot simply be 'competed away,' rendering competition law an essentially inapposite tool.

The Commission has thus long stated that it does not wish to act as quasiprice regulator in the context of its antitrust enforcement, ${ }^{39}$ albeit with recent suggestions of greater receptiveness. ${ }^{40}$ Correspondingly, our focus is price regulation in its more conventional guise. Yet, as shall be seen, competition policy considerations continue to suffuse EU law in this area. This is reflected in a prioritisation of 'genuine undistorted competition' 41 where possible, with a concomitant preference for independent commercial decision-making, ${ }^{42}$ in contradistinction to state ordering. The influence of competition policy is

\footnotetext{
32 Including fidelity-inducing rebates (e.g. Case T-286/09 Intel v Commission EU:T:2014:547), predatorily low prices (e.g. Case C-202/07 P France Télécom v Commission EU:C:2009:214), margin squeeze (e.g. Case C-280/08 P Deutsche Telekom v Commission EU:C:2010:603) and constructive refusal to deal premised upon unreasonably high prices (e.g. Case C-7/97 Oscar Bronner EU:C:1998:569).

33 Commission notice on remedies acceptable under Council Regulation (EC) No 139/2004 and under Commission Regulation (EC) No 802/2004 (OJ C 267/1, 22.10.2008), para.17.

${ }^{34}$ Echoing Ogus, Regulation: Legal Form and Economic Theory, Clarendon Press, Oxford (1994), 30.

35 O'Donoghue \& Padilla, The Law and Economics of Article 82 EC, Hart Publishing, Oxford (2006), 603.

36 See e.g. Case T-228/97 Irish Sugar v Commission EU:T:1999:246.

37 See Case 27/76 United Brands Company and United Brands Continentaal BV v Commission EU:C:1978:22.

${ }_{38}$ Note, e.g. the omission to address exploitative abuses within the Commission's Enforcement Priorities (fn.30 above), para.7.

39 European Commission, XXV IIth Report on Competition Policy (1997), 77.

40 See e.g. Speech of Competition Commissioner Vestager, "Protecting Consumers from Exploitation,"

delivered at the Chillin' Competition Conference, Brussels, 21 November 2016.

${ }^{41}$ Case C-322/81 NV Nederlandsche Banden Industrie Michelin v Commission EU:C:1983:313, para.57.

42 Case C-40/73 Suiker Unie EU:C:1975:174, para.173.
} 
moreover seen in a repurposing of antitrust concepts within the regulatory sphere, alongside various parallel antitrust enforcement efforts.

The task of constructing and regulating the internal market is a competence shared between the Union and its Member States. ${ }^{43}$ Regardless of whether they originate at national or EU levels, price controls fall within the ambit of EU law. ${ }^{44}$ Yet the issues raised by each category are quite distinct. Where national controls are at issue, the key questions are why and how the EU legal framework should intervene to constrain the regulatory choices of Member States within their domestic context. Where EU-level activity is at issue, the questions are when and how the EU institutions ought to exercise their discretion to mandate or impose price regulation within the internal market. Prior to exploring these dimensions, it is necessary to address several overarching complexities, which condition and may thus inform the differing approaches discernible within the EU legal framework.

First, price controls pose an inherent ideological challenge, insofar as the internal market is explicitly premised upon open and undistorted competition. Considerable emphasis is placed upon freeing markets not merely from private anticompetitive conduct, but from unnecessary or ineffective public restraints that diminish efficiency or impede integration. ${ }^{45}$ Implicitly, the free functioning of the price formation mechanism is essential to this. Although undistorted competition does not equate to unregulated competition, it reflects the ordoliberal preference for governmental interventions that aim, primarily, to buoy underlying market forces. ${ }^{46}$ In keeping with much modern economic theory, EU law thus has a distinct preference for solutions that aim to reinforce rather than overreach the market system. ${ }^{47}$ State-imposed limitations on price competition, conversely, constitute 'a particularly strong limitation of rights to property and the freedom of economic initiative.'48 Price regulation, insofar as it 'necessarily influences the freedom of the undertakings concerned to act in the market in question and hence the process of competition, ${ }^{49}$ is formally anathema to the underlying philosophy of the internal market.

Second, and linked to the priority granted to buttressing market forces in preference to dictating outcomes, the EU and its institutions operate at what Dashwood described as 'the intermediate level of policy execution'. ${ }^{50}$ Although the principles of direct effect and primacy mean that EU law creates rights and duties for individuals, the EU typically regulates via its Member States rather than through direct intervention in domestic markets, which instead lie largely within the regulatory purview of central and local governments. This limitation, moreover, reflects the sharing of jurisdiction within a Union that remains much less than a federation. The great bulk of price regulation occurring within the

\footnotetext{
43 Article 4(2)(a) TFEU.

44 See fn.26. above.

45 Recent pronouncements include C-100/05 Commission v Italy (Trailers) EU:C:2009:66, on free movement of goods, and C-554/12 P Commission v DEI EU:C:2014:2085, concerning Article 106(1) TFEU.

46 See, generally, Moschel, "The Proper Scope of Government Viewed from an Ordoliberal Perspective:

The Example of Competition Policy" 157 Journal of Institutional and Theoretical Economics 3 (2001).

47 See fn. 34 above.

48 Opinion in Vodafone, para.38.

${ }^{49}$ Case C-121/15 ANODE v Premier Ministre EU:C:2016:637, para.30.

50 Dashwood, "States in the European Union," 23 European Law Review 201 (1998), 213.
} 
internal market is devised and implemented at national level, with Member States demonstrating greater or lesser enthusiasm for economic interventions of this variety. The perceived necessity and tenor of such regulation is, furthermore, motivated primarily by domestic considerations, which raises concerns about capture, the quality of regulatory activity, and its potential for distortive wider effects.

Yet deference to domestic regulation can be defended insofar as the redistributive effects of price controls are legitimised by the political accountability of regulators and the link to a democratic mandate. ${ }^{51}$ These legitimating forces are weaker in the context of intervention originating in EU law, whether in the form of positive or negative integration efforts. ${ }^{52}$ Although criticism of the EU's 'democratic deficit' may be overstated, ${ }^{53}$ its infrastructure for democratic representation is at least one step further removed from citizens than in the national context. Given the extent to which price regulation represents a departure from standard laissez-faire models of regulation-but also that it may reflect societal preferences for valuable non-economic policy objectives-it seems appropriate to require a sufficiently robust degree of authority and accountability for decisions to regulate or not. Additionally, the nature of the regulatory process requires, typically, a detailed and nuanced understanding of the markets concerned, which may reinforce arguments for a decentralised model. ${ }^{54}$ Increasing criticism of the EU's one-size-fits-all approach to liberalisation, 55 for instance, suggests that more intensive forms of sector reorganisation may require a closer tailoring to market circumstances. (Conversely, it might be argued that the EU institutions are, instead, better placed to understand the Union-wide implications of price controls.56) Thus, the treatment of price regulation under EU law, occurring as it does at a further remove from regulated markets than analogous domestic processes, must be alive to potential criticisms on the bases both of democratic authority and effectiveness.

A third, related consideration draws upon the principle of subsidiarity, which governs the threshold question of when and whether positive action at EU (rather than national) level is appropriate. ${ }^{57}$ Essentially a principle of regulatory restraint, subsidiarity limits the EU's ability to act to situations where it is best placed to implement a top-down EU-wide solution. Linked to the notion that the EU remains 'a constitutional order of States, 58 subsidiarity reflects both recognition of

\footnotetext{
${ }^{51}$ Larouche, Competition and Regulation in European Telecommunications, Hart Publishing, Oxford (2000), 124. ${ }_{52}$ Majone, Dilemmas of European Integration: The Ambiguities and Piffalls of Integration by Stealth, OUP, Oxford (2005), 149-50.

${ }^{53}$ Compare Moravcsik, "In Defence of the 'Democratic Deficit': Reassessing Legitimacy in the European Union," 40 JCMS 603-24 (2002), and Follesdal \& Hix, "Why There is a Democratic Deficit in the EU: A Response to Majone and Moravcsik," 44 JCMS 533-62 (2006).

${ }^{54}$ See also Barnard (2016), 17.

55 See e.g. Mizutani \& Uranishi, "Does vertical separation reduce cost? An empirical analysis of the rail industry in European and East Asian OECD Countries" 43 Journal of Regulatory Economics 31-59 (2013). 56 de Witte, "Sex, Drugs and EU Law: The Recognition of Moral and Ethical Diversity in EU Law," 50 CMLRev 1545 (2013), 1553-54.

${ }^{57}$ In areas outside its exclusive competence, the EU may act only if and insofar as the proposed objectives cannot be sufficiently achieved by Member States, but can rather, by reason of scale or effects, be better achieved at Union level: Article 5(3) TEU.

${ }^{58}$ Dashwood (2000), 216.
} 
the Member States' continued existence as sovereign states, ${ }^{59}$ and more cynically, continued resistance to centralisation or even federalisation of Europe. ${ }^{60}$ As Öberg argues, 'the core of subsidiarity is the right of Member States to diverge'61_an (ostensible) right of particular relevance in the context of price controls.

Positive efforts at price regulation-whether alignment of domestic regulatory structures, or price controls implemented directly through EU lawhave generated some of the most notable recent challenges in the context of the subsidiarity principle. ${ }^{62}$ As a shared competence, subsidiarity clearly constrains the $\mathrm{EU}$ when regulating the internal market. ${ }^{63} \mathrm{In}$ the context of much price regulatory activity, this threshold requirement for EU-level action may be difficult to satisfy. Price controls not only can and have been implemented successfully by national regulatory authorities, but the price-setting process may benefit from a closer relationship between regulator and market. ${ }^{64}$ Moreover, price controls involve significant incursions into both the economic independence of market actors and the residual freedom of Member States to make redistributive choices with respect to day-to-day running of national economies. ${ }^{65}$ Where positive integration is at issue, the principle of subsidiarity thus suggests that intervention at EU level is likely to be appropriate only where there are clear cross-border issues at stake which, moreover, pose insurmountable hurdles to national regulators-what Öberg labels 'transnational market failures' 66 . Even where this is the case, price regulation must be a proportionate response. ${ }^{67}$

In areas of negative integration-for instance, where the Court of Justice scrutinises domestic controls - the principle of subsidiarity is not formally binding. There is, nevertheless, an argument that the multi-layered constitutional structure of the EU means that it ought to be respected in spirit. That is, mere divergence that is reflective of differing national preferences should not be viewed as inherently suspect. This is of importance when considering whether EU law ought to pre-empt regulatory choices at the national level: in essence, we must consider which polity is entitled to make the sorts of policy choices, both economic and social, reflected within price regulatory activity. ${ }^{68}$ This links, moreover, to the vital question of proportionality, meaning, in this context, the extent to which EU law should probe the appropriateness, in substance, of price regulatory choices at the domestic level. 69

Accordingly, for a variety of ideological, constitutional and even practical reasons, price regulation occupies an uneasy position within the EU legal

\footnotetext{
59 Dashwood (2000), 211.

${ }^{60}$ Craig, "Subsidiarity: A Political and Legal Analysis," 50 JCMS 72 (2012), 73.

61 Öberg, "Subsidiarity as a Limit to the Exercise of EU Competences" Yearbook of European Law

(forthcoming, 2016), 15

62 See fn.10 above.

63 Article 4(2)(a), TFEU

64 Majone (2005), 149-50.

65 See, generally, Höpner \& Schäfer, "A New Phase of European Integration: Organised Capitalisms in

Post-Ricardian Europe" 33 West European Politics 344 (2010).

66 Öberg (2016), 8.

67 Article 5(4), TEU

68 Scharpf, Governing in Europe: Effective and Democratic? OUP, Oxford (1999), 63.

${ }^{69}$ See e.g. Case C-94/04 Federico Cipolla v Rosaria Fazari EU:C:2006:758, para.61.
} 
framework. Disfavoured but not proscribed, its treatment reflects a compromise between the archetype of free competition, the imperative of effective market governance, and the peremptory nature of certain non-economic concerns. The complexity of the balancing exercise is demonstrated by the range of approaches discernible within the case-law and practice of the EU: an antagonistic probibitive approach, a permissive approach premised upon EU-level supervision of domestic regulation, and a prescriptive approach involving positive price controls. The first and second of these involve, primarily, indirect control of disparate domestic price regulatory efforts, while the third relates, exceptionally, to price regulation imposed directly through EU law. Yet, within each broadly equivalent tensions can be seen, raising issues of technical expertise and democratic authority, while reflecting what de Witte describes as arguments for self-determination versus containment of distortive domestic preferences within the social market economy. ${ }^{70}$ Each approach is examined in turn, bearing in mind the considerations above.

\section{INDIRECT PRICE REGULATION I: THE PROHIBITIVE APPROACH}

Arguably, the default approach within the internal market is, in keeping with its ideological tenor generally, one of deep scepticism and reluctance towards price regulation. We term this the probibitive approach: as a derogation from the precept of open and undistorted competition, price controls are incompatible with the EU legal framework unless justified by a legitimate and proportionate objective. This suspicion is illustrated, implicitly albeit most convincingly, by the sheer absence of price regulation within positive EU law. ${ }^{71}$ Instead, most EU legal rules addressing this question concern efforts to constrain or prohibit price controls implemented at national level, most obviously through the free movement rules.

The fundamental rules guaranteeing free movement within the internal market provide its legal foundation, prohibiting domestically-imposed obstacles to the circulation of goods, services, establishment, workers and capital between Member States. Price regulation poses a conceptual conundrum here. As described above, price controls are close to the antithesis of free unencumbered competition between private market actors, and thus present a fundamental departure from the archetype of 'open' competition underpinning the internal market. Yet, formally, the free movement rules are not concerned with barriers to competition as such, but instead, with barriers to trade (and, by consequence, competition) between different national markets that comprise the discrete components of the ostensible single market. While EU law pursues the clear goal of market interpenetration through removal of barriers to trade, the internal market does not mandate that

\footnotetext{
70 de Witte (2013), 1546-56.

${ }^{71}$ We distinguish between quasi price-setting relating to 'markets' essentially created by EU law-e.g. levels of aid under the Common Agriculture Policy, or tariffs under the Common Commercial Policyand price regulation of 'economic activity' (Case C-41/90 Höfner EU:C:1991:161, para.21) in the internal market.
} 
such trade is wholly unregulated at national level, provided the domestic regulatory framework does not impose an implicit barrier to foreign competition. Free movement is not precisely equivalent to 'free markets,' therefore, insofar as the latter implies unrestricted economic activity more generally. ${ }^{72}$

A conceptual distinction can be drawn between national rules that limit the commercial freedom of all economic operators, whether originating in the home or another Member State, and those which make life more difficult for foreign manufacturers or service providers, and thus hinder market interpenetration. ${ }^{73}$ Domestic price controls clearly limit the ability of traders to determine, privately and independently, the price of goods or services sold within the internal market. As such, price regulation has the potential to dampen and distort competition in absolute terms. ${ }^{74}$ Provided such regulation disadvantages domestic and foreign traders to an equivalent extent, however, it cannot constitute a barrier to trade between Member States, but merely a restriction on trade within a national market. Unlike other ostensible 'selling arrangements, ${ }^{75}$ moreover, price controls do not generate an obvious incumbency advantage for established domestic operators, by, for instance, imposing a positive obstacle to entry ${ }^{76}$ or restricting the possibility of cross-border sales 77 -beyond, of course, making the market potentially less profitable and thus less desirable to entrants. Moreover, the mere fact that certain Member States refrain from regulating prices, or do so less restrictively, cannot imply that more exacting regulation elsewhere poses an obstacle to free movement. ${ }^{78}$

Convincing though this logic is, the Court of Justice has nonetheless proven receptive to arguments that apparently neutral controls may impose barriers to accessing national markets which constitute a particular disadvantage for traders from other Member States. While acknowledging the residual freedom of Member States to regulate in the absence of EU-level harmonisation, the Court has held that price controls might obstruct the free movement of, variously, goods, ${ }^{79}$ services $^{80}$ and establishment. ${ }^{81}$ The Court's reasoning suggests a deep appreciation of the significance of price within the market process, in terms of both the competitive vitality and economic viability of economic actors. This, in turn, arguably links to ordoliberal thinking on the centrality of individual economic freedom within the economic constitution. ${ }^{82}$ These cases thus reflect the ideological tension that arises where domestic controls limit or distort competition

\footnotetext{
72 For discussion of the market access principle, and its implicit limits, see Barnard (2016), 19-24.

73 Case C-267/91 Keck and Mithouard EU:C:1993:905, paras.14-17.

74 Ibid, para.13.

75 Ibid, para. 16

76 As in Case C-34/95 Konsumentombudsmannen (KO) v De Agostini (Svenska) Förlag AB EU:C:1997:344.

77 As in Case C-108/09 Ker-Optika bt v ÀNTSZ Dél-dunántúli Regionális Intézete EU:C:2010:341.

78 C-565/08 Commission v Italy EU:C:2011:188, para.49.

${ }^{79}$ See e.g. Scotch Whisky. While Keck held that certain types of price regulation should fall entirely outside Article 34 TFEU where applied equally and without discriminatory impact, Scotch Whisky suggests that price controls are likely to be viewed as a 'measure having equivalent effect' hindering market access and thus, prima facie, an infringement (para.32, following the approach of the Opinion, paras.59-60).

80 See e.g. Cipolla

81 See e.g. Cases C-465/05 Commission v Italy EU:C:2007:781, and C-442/02 CaixaBank France v Ministère de l'Économie, des Finances et de l'Industrie EU:C:2004:586.

82 See e.g. Lovdahl-Gormsen, A Principled Approach to Abuse of Dominance, CUP (2010), 95-104.
} 
within the ostensibly free internal market-a tension particularly apparent in several recent decisions. ${ }^{83}$ These dual concerns may help to explain why, in evaluating the treatment of domestic price regulation, one leading commentator suggests that, without saying so explicitly, the Court views such cases as a distinct—and arguably atypical — category. ${ }^{84}$

On the one hand, price controls may hinder access to national markets by limiting the competitive vitality of traders from other Member States: as the Court of Justice held forcefully in its Deutsche Parkinson judgment: 'price competition lays the basis for [foreign traders'] potential to access the [host] market directly and to continue to be competitive in it. ${ }^{85}$ Cases in this vein signify that price is the most immediate parameter of competition. Where regulation restricts, de jure, the ability of new entrants to compete on price, this may have the effect, de facto, of preventing entrants from competing at all. This might be the case where particular goods can be produced more cheaply in the home Member State-echoing the classic Ricardian notion of comparative advantage-yet where fixed or minimum price controls within the host Member State prevent the foreign trader from reaping the competitive advantage of its lower costs. ${ }^{86}$ Alternatively, regulation may deprive entrants of the effective competitive strategies necessary to break into new markets and increase market share. Price controls may prevent entrants from engaging in innovative pricing practices, which might distinguish their services from those of domestic incumbents; 87 from using price competition to overcome reputational or other incumbency advantages of established domestic undertakings; 88 or, where foreign traders are at an inherent disadvantage in terms of the quality of the service they can provide, from compensating customers through lower prices. ${ }^{89}$ Finally, limitations on price competition may stifle the ability of new entrants to compete in terms of higher quality, where the effect is to prevent the foreign trader from offering goods/services which, though more costly, represent added value for consumers. ${ }^{90}$

On the other hand, price controls may hinder access by threatening the economic viability of new entrants within the host Member State. The dividing line between happiness and misery in Dickensian parlance, achieving a positive equilibrium between income and costs is necessary to ensure that entrants can remain within the marketplace and potentially develop as effective competitors. Price regulation might function to exclude foreign traders, however, where a fixed or maximum selling price is set at an unreasonably low level in comparison to their costs. ${ }^{91}$ Such an outcome may arise, in particular, where a pricing scheme is

\footnotetext{
83 In particular, the movement away from Keck, considered below, supports this view: contrast the earlier approach of Poiares Maduro, "Reforming the Market or the State? Article 30 and the European

Constitution: Economic Freedom and Political Rights" 3 European Law Journal 55 (1997), 65.

84 Barnard (2016), 87, fn.127.

85 Deutsche Parkinson, para.24.

86 See e.g. Case C-82/77 Openbaar Ministerie (Public Prosecutor) of the Kingdom of the v Jacobus Philippus van

Tiggele EU:C:1978:10, paras.14\&18.

87 Caixa-Bank France, paras.12-14.

${ }^{88}$ Cipolla, para.59; Case C-465/05 Commission v Italy, para.125.

${ }^{89}$ Case C-148/15 Deutsche Parkinson Vereinigung eV v Zentrale zur Bekämpfung unlauteren Wettbewerbs eV EU:C:2016:776, paras.24-27.

${ }^{90}$ Case C-465/05 Commission v Italy, para.119.

91 See e.g. Case C-65/75 Riccardo Tasca EU:C:1976:30, para.13.
} 
devised only by reference to the situation of undertakings established in the host Member State, which differs from that of foreign undertakings. ${ }^{92}$ Here, the domestic controls generate what is in effect a margin squeeze-a concept firmly established in the context of Article 102 TFEU 93 -between costs incurred by the foreign trader upstream and the maximum price obtainable downstream. The effect is that the foreign trader cannot compete profitably-and, thus, in the longer term, probably cannot compete at all-in the host Member State. ${ }^{94}$ Cases of this variety thus grapple with a limitation inherent within the truism that competition policy ought to protect the competitive process rather than competitors as such: although the latter might introduce inefficiencies in the shorter term, in the longer term the existence of rivals is indispensable to healthy competition.

Finally, several recent cases may hint at a more fundamental objection to price regulation, reflecting the antithetical nature of price controls within an ostensibly free market. Chief amongst these is Scotch Whisky, noted above. In holding that the domestic regulation of alcohol pricing constituted a 'measure having equivalent effect' (MEE) contrary to Article 34 TFEU, the Court spoke broadly about the potential for price regulation to impinge upon 'the free formation of prices, ${ }^{25}$ which 'constitutes the expression of the principle of free movement of goods in conditions of effective competition.'96 Such language suggests that the concern with price regulation is not merely that it may disfavour foreign traders, but moreover that it may create an inherently uncompetitive market structure which disadvantages all traders-and, consequently, consumers-regardless of origin.

Care ought to be taken, of course, against reading too much into the language of a single judgment. First, the phrase, 'the free formation of prices,' was introduced by the Advocate General97 specifically in relation to the revised CMO Regulation for agricultural products, ${ }^{98}$ although the Court adopted the wording within a broader context. ${ }^{99}$ Moreover, in concluding that the impugned price controls constituted a MEE, the Court endorsed the reasoning of the Advocate General, ${ }^{100}$ who emphasised the extent to which the regulation might cancel out the competitive advantage of imports, ${ }^{101}$ thus linking its holding to established case-law. ${ }^{102}$ Yet, the apparently expansive language chimes with the earlier case of Commission v Italy, in which the Court spoke of price regulation as a potential impediment to market access-contrary, in that instance, to Articles 49 and 56

\footnotetext{
92 See e.g. Opinion of Advocate General Poaires Maduro in Case C-94/04 Federico Cipolla v Rosaria Fazari EU:C:2006:76, para.69.

93 See e.g. Case C-52/09 Konkurrensverket v TeliaSonera Sverige AB EU:C:2010:483, para.63

94 See, to this effect, Tasca, para.10.

95 Scotch Whisky, para.44.

96 Ibid, para. 20

97 Opinion in Scotch Whisky, para.37.

98 Regulation (EU) No 1308/2013 of 17 December 2013 establishing a common organisation of the markets in agricultural products and repealing Council Regulations (EEC) No 922/72, (EEC) No 234/79, (EC) No 1037/2001 and (EC) No 1234/2007 (OJ L 347/671, 20.12.2013).

99 Scotch Whisky, para.44.

$100 \mathrm{Ibid}$, paras.31\&32.

101 Opinion in Scotch Whisky, para.59-60

102 See e.g. van Tiggele, subsequently cited in the Opinion in Scotch Whisky, para.65.
} 
TFEU-insofar as it might deny entrants the opportunity to compete 'under conditions of normal and effective competition' within the host Member State. ${ }^{103}$ Again, this suggests that it is not merely the potentially discriminatory impact of such regulation, but rather its distortive effects more generally, which conflict with the framework of open competition. ${ }^{104}$ Although the Court concluded that the regulation did not, in fact, hinder market access, it did so on the basis that, in practice, it permitted independent price-setting, thus allowing 'proper remuneration'105_and, implicitly, allowing the market mechanism to function. A principled objection to interference with the price formation mechanism may also explain the vehemence of the Court in Deutsche Parkinson, which celebrates the virtues of price competition in the strongest terms. ${ }^{106}$

Regardless of the conceptual basis upon which price regulation might constitute a barrier to free movement, Member States retain the possibility of justifying - thus 'saving'- such controls by reference to proportionate countervailing public policy considerations. It is at this juncture that the domestic impetus behind price regulation is of paramount significance: whilst EU law acknowledges the importance, and possible precedence, of certain 'non-economic public policy aims, ${ }^{107}$ not every domestic concern provides a legitimate reason to deviate from the general approach of open competition. To exempt prima facie restrictive regulation, Member States must demonstrate that it 'serves overriding requirements relating to the public interest, is suitable for securing the attainment of the objective which it pursues and does not go beyond what is necessary in order to attain it'. ${ }^{108}$ The burden on proof lies on the Member State, ${ }^{109}$ emphasising the presumption that national obstacles to price competition conflict with EU law.

In scrutinising any public policy objective advanced to justify price regulation, the core question is the extent to which EU law can or should presume to 'second guess' the policy choices of Member States. The free movement rules are not a prescription for legislative harmonisation, ${ }^{110}$ and Member States retain freedom for divergent regulation within their confines. Price regulation, alongside the domestic policy concerns that underpin it, is often an inherently political activity, ${ }^{111}$ both in its initial recognition of legitimate countervailing non-economic values and in the choice of regulatory mechanisms deployed to protect or further those values. ${ }^{112}$ To that extent, one might argue, "[i]t is obviously not for the Court to interfere in national political and democratic processes and to prejudge certain

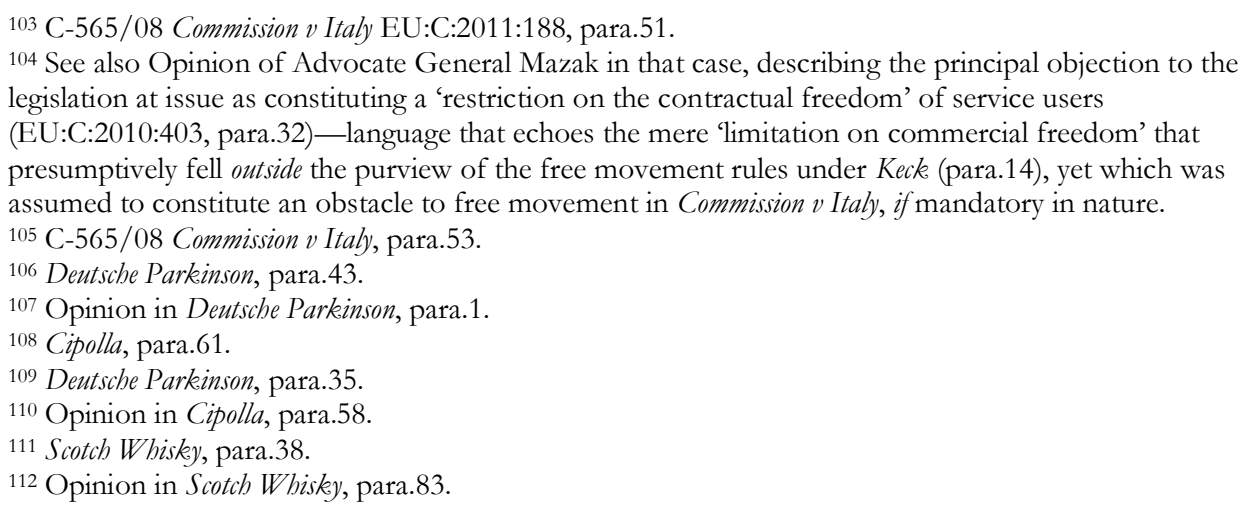


political choices.' ${ }^{113}$ Yet, as cases like Essent, ${ }^{114}$ Viking, ${ }^{115}$ and Laval ${ }^{16}$ demonstrate in different contexts, the mere fact that fundamental domestic policy considerations are at issue neither excludes application of the free movement rules nor means that the latter must yield to the former. Balancing the primary objective of establishing the internal market against 'sensitive matters of a non-economic nature' 117 is, therefore, 'a delicate task'. ${ }^{118}$

Member States are allowed relatively broad latitude in identifying public policy concerns that might, in theory, justify restrictions on price competition. Echoing the discussion in section II above, the Court accepts that controls on price might further such objectives in a variety of ways. Upper limits can enhance consumer protection by preventing price gouging, particularly where consumers lack market power. ${ }^{119}$ Price regulation may encourage practices viewed as socially desirable_ such as consumer saving 120 _ or, conversely, to discourage undesirable practices-such as alcohol abuse. ${ }^{121}$ More problematic are cases where price controls are intended to play a 'moderating role,'122 to neutralise perceived 'excessive' 123 or 'ruinous'124 competition. Here, the regulatory concern is that price competition might unbalance the existing market equilibrium by, for instance, encouraging 'cream-skimming' behaviour that neglects peripheral or vulnerable consumers ${ }^{125}$ or less profitable product categories, ${ }^{126}$ or which leads to a deterioration in quality as suppliers cut costs in order to cut prices. ${ }^{127}$ While the Court is not unreceptive to such concerns, ${ }^{128}$ justifications of this variety may shade into purely economic arguments, which cannot provide a legitimate ground for derogating from free movement. ${ }^{129}$

The mere existence of a valid public policy concern does not automatically legitimate domestic price controls, however, as Member States are furthermore bound by the principle of proportionality. Any regulation must therefore be limited to measures that are both suitable and necessary to achieve the relevant public policy objective. ${ }^{130}$ The exactingness with which the proportionality criterion is applied is, arguably, the decisive aspect of the balancing of domestic and EU-level interests in this context. Advocate General Bot thus argued for 'a

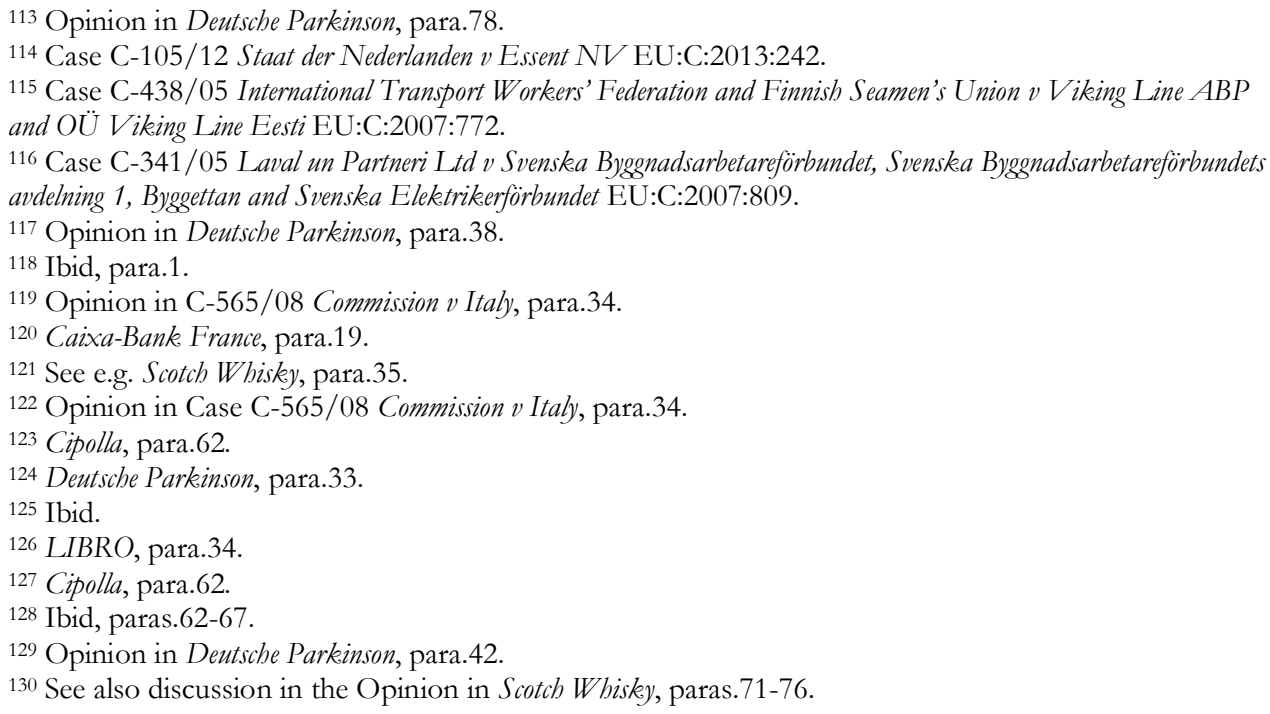


certain degree of restraint' in conducting this analysis:131 in order to grant Member States some discretion over policy choices on issues of, primarily, domestic concern; ${ }^{132}$ and due to the inherent ambiguity of the exercise, involving a measuring and balancing of fundamentally different (and, sometimes, intangible and even unknowable) phenomena. ${ }^{133}$ In Scotch Whisky, the Court accordingly adopted a reasonableness standard in assessing whether the proportionality requirement was satisfied: ${ }^{134}$ an approach that gives Member States a certain leeway, reflecting the once-removed status of the EU institutions in relation to the essentially domestic policy choices that underlie most price regulation. ${ }^{135}$

Yet, the Court's recent decisions on price regulation suggest, in practice, an approach to that is more exacting than the language of reasonableness might imply. In particular, the Court has shown few qualms about questioning, and effectively second-guessing, domestic choices in an area acknowledged to be of significant importance-human health—and one which, moreover, lies primarily within the competence of Member States. ${ }^{136}$ Thus, in Scotch Whisky itself, a decidedly unconvinced Court indicated that, although minimum pricing might be a suitable means to combat alcohol misuse, it should not be considered necessary, insofar as a tax increase could achieve essentially the same result while being less restrictive of trade. ${ }^{137}$ (A viewpoint rejected, notably, when the case returned to the domestic level. ${ }^{138}$ )

Even more trenchantly, in Deutsche Parkinson, the Court rejected categorically Germany's assertion that fixed prices were suitable to protect the supply of medicinal products by supporting a network of bricks-and-mortar pharmacies, despite the referring court's view that regulation was the only means available (and thus, necessary) to achieve this outcome. Although the holding may be explained partly by an absence of plausible evidence, ${ }^{139}$ the case is nonetheless remarkable for the willingness of the Court to substitute its own (equally subjective) reasoning for that of the delinquent Member State. Of particular significance is its receptiveness to certain — markedly hypothetical140_arguments advanced by the Advocate General to provide a counter-narrative to that of the Member State, including suggestions in respect of the potential effects of price competition; ${ }^{141}$ and, in a manner arguably conflating ought with is, the ways in which internet-only

\footnotetext{
131 Opinion in Scotch Whisky, para.82.

132 Ibid, para. 83.

133 Ibid, para. 84

134 Scotch Whisky, paras.36\&56.

135 See also de Witte (2013), 1570-71.

136 Article 6(a) TFEU.

137 Scotch Whisky, paras.45-50.

138 'The fundamental problem with an increase in tax is simply that it does not produce a minimum price': The Scotch Whisky Association and Others v The Lord Advocate and the Advocate General [2016] CSIH 77, para.196.

139 The Court emphasised that Member States must discharge their burden of proof, 'not according to the yardstick of general conjecture, but on the basis of relevant scientific research': Deutsche Parkinson, para.42. 140 In distinction to the 'gradual empirical turn' noted within the Court's approach to proportionality analysis: see, generally, Alemmano (2016), 1049.

141 The Court was thus persuaded that price competition was at least as likely to generate higher quality services than the lower quality ones feared by Germany (para.40, adopting reasoning of the Opinion, para.47): arguable, yet wholly speculative, and curiously missing any consideration of possible free-riding effects that are a central concern of contemporary antitrust discourse.
} 
pharmacies might serve all segments of the population. ${ }^{142}$ Thus, the Court effectively questioned the substance of the domestic policy choices. ${ }^{143}$ What remains unclear is the source of this hostility: that is, whether the Court was concerned about inadvertently poor quality national regulation, or, echoing public choice critiques, whether it suspected a disjuncture between stated and actual regulatory motives. Either antagonism might bring attendant dangers, however: an unduly rigorous and somewhat speculative proportionality analysis risks slipping from a judicial to full-merits review standard; whereas questioning the underlying motives of a Member State in this manner might run contrary to the principle of mutual trust that is demanded, at least of Member States, under EU law. Ultimately, the key question is why the Court of Justice might be better placed to make such (essentially normative) determinations, whether based on technical expertise or its pan-Union perspective. ${ }^{144}$ The apparent willingness of the Court to embrace substantive review stands in marked contrast, moreover, to its reluctance to perform a broadly similar function under the subsidiarity principle in the context of price regulation originating at $E U$ level. ${ }^{145}$

Where, more exceptionally, Member States involve private market actors in the public task of price regulation, competition law may provide an alternative avenue to scrutinise and prohibit such behaviour. As noted, where anticompetitive price-setting is carried out by undertakings themselves, it may be caught by Articles 101 or 102 TFEU. To avoid a situation where equivalent private interests are cloaked in public authority and escape scrutiny, those prohibitions - read with Article 5 TEU (duty of loyal cooperation)—also impose obligations on Member States. ${ }^{146}$ This may be the case where Member States require or encourage abusive price-setting by dominant undertakings or adoption of rate-fixing agreements between undertakings, or where national rules lose the character of public legislation if responsibility is delegated to private operators for decisions affecting the economic sphere. ${ }^{147}$ Alternatively, where anticompetitive pricing structures are maintained by an undertaking yet attributable to a state measure, the Member State may be accountable under Article 106(1) TFEU.148 Where, however, price regulatory activity is necessary to ensure provision of so-called 'services of general economic interest,' Article 106(2) TFEU may exempt the behaviour from application of, inter alia, competition law. ${ }^{149}$

142 'People with reduced mobility could greatly benefit from being able to place orders online and having them delivered directly to their home. Even if they are not accustomed to the alleged intricacies of ordering online, they will often have someone at their side (a carer, a (grand)child, a neighbour etc.) who is': Opinion in Deutsche Parkinson, para.52, endorsed by the Court at para.37.

143 On the implication of a substantive principle of proportionality in an analogous context, see de Witte (2013), 1566-70.

144 See the concerns expressed by de Witte (2013), 1569-70.

${ }^{145}$ Rationalising the reluctance of the Court of Justice to engage in substantive subsidiarity analysis, see Öberg (2016), 16-17.

146 See also discussion in the Opinion in Cipolla, paras.31-37.

${ }_{147}$ Cipolla, para.47. As Cipolla demonstrates, the threshold for finding violation is high (paras.44-54).

148 See e.g. Commission Decision of 10 February 1999 in Case No.IV/35.703_Portuguese airports (OJ L 69/31, 16.3.1999).

149 See e.g. Case T-289/08 BUPA v Commission EU:T:2008:29, where the Court accepted that a Stateimposed 'risk equalisation scheme,' which required transfer payments between private health insurers and had the effect of standardising consumer premiums, could be exempted on this basis. 


\section{INDIRECT PRICE REGULATION II: THE PERMISSIVE APPROACH}

Although an openly sceptical approach typically governs ad hoc instances of domestic price regulation, within a narrower subset of economic conditions there is greater recognition of, if not the desirability of price controls, at least their inevitability. In these latter circumstances-marked by distinctive market features, and accompanying broader EU-level harmonisation efforts- the approach is less hostile. Reflecting, perhaps, a pragmatic recognition of the (sometimes) necessity of intervention, the 'lesser evil'150 is thus to centralise and standardise arrangements for domestic regulation through an overlay of more permissive, essentially supervisory EU rules. Price controls are not treated as inherently suspect, nor presumed to be incompatible with the competitive structure of the internal market; yet the discretion of Member States is constrained, with an underlying assumption that the scope for resultant market distortions is similarly diminished.

The granular details, and relative strictness, of the supervisory schemes differ between sectors: consideration is given below to the approach in the electricity, telecommunications, airport and pharmaceutical markets, while further examples are found in the regulatory frameworks for natural gas, ${ }^{151}$ railways, ${ }^{152}$ and groundhandling. 153 Yet, those circumstances where default hostility is replaced by tentative tolerance nonetheless share characteristics which inform and influence the tenor of supervision. First, each of the sectors concerned has been subject to some degree of EU-level sector-specific liberalisation and/or harmonisation, which sought to transform tightly-controlled and segmented national markets into contestable and competitive components of the broader internal market. EU law has thus been the ultimate catalyst for creation of the ostensible market forces which Member States might subsequently seek to restrict through price controls. Adoption of positive legislation also suggests pan-Union interests which might otherwise be imperilled through disparate domestic regulation.

Second, in each of these sectors, liberalisation has not, however, involved a complete realignment of market governance rules with any EU-level archetype. ${ }^{154}$ Member States thus retain scope to adopt divergent regulation, which might have such disruptive effect. Absent deeper harmonisation-which, in the areas concerned, would prove politically contentious as well as potentially inefficientthe more pragmatic approach may be indeed to accept the possibility of diversity but take efforts to minimise its potentially disruptive impact.

Finally, the sectors concerned are, typically, marked by structural featuressignificant economies of scale, network effects, natural or legal monopoly components-which mean that unregulated market activity is unlikely to generate

\footnotetext{
${ }^{150}$ Echoing language in the Opinion of Advocate General Szpunar in Deutsche Parkinson, para.79.

151 Directive 2009/73/EC of 13 July 2009 concerning common rules for the internal market in natural gas and repealing Directive 2003/55/EC (OJ L 211/94, 14.8.2009), Articles 3(2) \& 41(1)(a).

152 Directive 2012/34/EU of 21 November 2012 establishing a single European railway area (OJ L 343/32, 14.12.2012), Articles 29-36.

153 Council Directive 96/67/EC of 15 October 1996 on access to the groundhandling market at Community airports (OJ L 272/36, 25.10.1996), Article 16(3).

154 In keeping with the logic of the shared competences: Article 4 TFEU.
} 
'effective' competition even after ostensible liberalisation, so that ordinary price formation mechanisms may generate suboptimal outcomes. ${ }^{155}$ These difficulties are reflected, inter alia, in the frequency with which competition enforcement has been deployed against individual pricing practices within these markets. ${ }^{156}$ Moreover, in the background in most instances are societal concerns-such as public service provision, or public health-that extend beyond the purely economic. These factors explain why domestic price controls are implemented with notable frequency in such markets: 'Mliberalisation, if it is not to be at any cost to individuals, makes a certain amount of regulation necessary when the market does not function adequately. ${ }^{\prime} 57$ These economic and social features may thus provide a rationale for EU-level acceptance of regulation on a 'lesser evil' basis. 158

The electricity sector, where the continued presence of natural monopoly segments creates persistent structural barriers to competition, provides a clear example of this more permissive approach. Here, although the ultimate objective is to secure 'transparent market-based mechanisms for the supply and purchase of electricity,' 159 the liberalisation framework acknowledges the continuing necessity for price supervision. The Third Electricity Directive thus expressly permits Member States to impose public service obligations with respect to, inter alia, price. ${ }^{160}$ It moreover requires Member States to ensure universal service for household customers (and, if preferred, small enterprises), premised upon 'reasonable, easily and clearly comparable, transparent and non-discriminatory prices.'161 Perhaps most notably, the Directive mandates regulatory approval of transmission and distribution tariffs. ${ }^{162}$ This approach gives due recognition to the 'essential facility' nature of such infrastructure-a parallel to the realm of

\footnotetext{
155 See e.g. Lovdahl-Gormsen (2010), 92, arguing that price regulation is a natural implication of supporting less-efficient competitors in liberalising markets.

156 In the telecommunications sector, see e.g. Cases C-202/07 P France Télécom SA v Commission EU:C:2009:214, C-280/08 P Deutsche Telekom AG v Commission EU:C:2010:603 and C-295/12 P Telefónica $S A$ and Telefónica de España SAU v Commission EU:C:2014:2062. In the electricity sector, see e.g. Commission Decision of 26 November 2008 in Cases COMP/39.388-German Electricity Wholesale Market and COMP/39.389-German Electricity Balancing Market (OJ C 36/8, 13.2.2009). In relation to airport charges, see e.g. Commission Decision of 10 February 1999 in Case No IV/35.703_Portuguese airports (OJ L 69/31, 16.3.1999); Commission Decision of 10 February 1999 in Case No IV/35.767Ilmailulaitos/Lufffartsverket (OJ L 69/24, 16.3.1999); and Commission Decision of 26 July 2000 (Spanish Airports) (OJ L 208/36, 18.8.2000). In relation to pharmaceutical products, the markets distortions introduced by differentiated domestic price controls were explored in the (in)famous judgment in Case C501/06 P GlaxoSmithKline Services Unlimited v Commission EU:C:2009:610; more recently, national competition authorities in Italy and the UK have found infringements of Article 102 TFEU based on excessive pricing.

157 Opinion of Advocate General Ruiz-Jarabo Colomer in Case C-265/08 Federutility and Others v Autorità per l'energia elettrica e il gas EU:C:2009:640, para.43.

${ }_{158}$ Tracing the evolution of a 'social dimension' in the context of electricity liberalisation, for instance, see Haber, "Liberalising Markets, Liberalising Welfare? Economic Reform and Social Regulation in the EU's Electricity Regime", Journal of European Public Policy, forthcoming 2017.

${ }^{159}$ Recital (35), Directive 2009/72/EC of 13 July 2009 concerning common rules for the internal market in electricity and repealing Directive 2003/54/EC (OJ L211/55, 14.8.2009) ('Electricity Directive').

160 Ibid, Article 3(2).

161 Ibid, Article 3(3)

162 Ibid, Articles 32(1) and 37(1)(a).
} 
antitrust $\mathrm{t}^{163}$ - yet stands at odds with any deeper understanding of liberalisation as the removal of state market controls. In line with the logic of the permissive approach, however, the liberalisation framework does not presume to determine access prices; instead, the task is delegated to national regulators, albeit acting within the circumscribed EU supervisory framework.

Within the telecommunications sector, where EU liberalisation has met with greater success, ${ }^{164}$ the treatment of domestic regulation is less generous. Here, liberalisation is explicitly premised upon progressive reduction of ex ante regulation as competition develops. ${ }^{165}$ Thus, there is an express preference for access and supply arrangements negotiated 'on a commercial basis', 166 which implies pricesetting in accordance with ordinary principles of supply and demand where possible. While the liberalisation framework provides explicit authorisation for domestic price controls where necessary, ${ }^{167}$ this option is only available following a finding that one or more operators hold 'significant market power'. ${ }^{168}$ This concept mirrors the antitrust notion of dominance, ${ }^{169}$ premised upon an absence of competitive constraints, thus suggesting that ordinary price-setting processes cannot work well in the circumstances. ${ }^{170}$ Nonetheless, regulatory interventions must avoid 'market distortion'171 which might prove counterproductive on balance. Market assessments are subject to periodic review, ${ }^{172}$ with an attendant obligation to remove existing regulation where the threshold requirement is not met. ${ }^{173}$ Furthermore, the Commission has progressively narrowed the list of markets in which price controls might be warranted. ${ }^{174}$ Accordingly, despite express recognition of the residual permissibility of regulation even within ostensibly liberalised markets, the discretion of Member States to impose price controls is significantly curtailed, at least acting qua telecommunications regulators. ${ }^{175}$

\footnotetext{
${ }^{163}$ For discussion of this doctrine within EU competition law, see Case C-7/97 Oscar Bronner EU:C:1998:569.

164 Pelkmans \& Luchetta, Enjoying a Single Market for Network Industries? Notre Europea-Jacques Delors Institute, Studies \& Reports 95 (February 2013), 31.

165 Recital (13), Directive 2002/19/EC of 7 March 2002 on access to, and interconnection of, electronic communications networks and associated facilities (OJ L 108/7, 24.4.2002) ('Access Directive').

166 Ibid, Recital (5).

167 Ibid, Article 13

168 Ibid, Article 8.

${ }^{169}$ Namely, 'a position of economic strength affording [an undertaking] the power to behave to an appreciable extent independently of competitors, customers and ultimately consumers': Article 14(2), Directive 2002/21/EC of 7 March 2002 on a common regulatory framework for electronic communications networks and services (OJ L 108/33, 24.4.2002) ('Framework Directive'), reflecting the classic definition from United Brands, para.65.

${ }^{170}$ See the Commission's Enforcement Priorities, fn.30 above, para.11.

171 Recital (7), Access Directive.

172 Ibid, Article 7.

173 Article 16(3), Framework Directive.

${ }^{174}$ In accordance with Article 7(2), Access Directive; compare the ever-diminishing approach in the Commission Recommendations of 11 February 2003 (OJ L144/45, 8.5.2003), 17 December 2007 (OJ L344/65, 28.12.2007) and 9 October 2014 (OJ L295/75, 11.10.2014), respectively.

175 Member States retain residual ability to regulate on alternative bases, for instance under consumer protection powers: Vodafone, para.43.
} 
The Directive on Airport Charges ${ }^{176}$ provides another variation on this indirect approach to supervision of domestic regulation. While the explicit aim is to establish a common regulatory framework for charges at major EU airports, ${ }^{177}$ the Directive stops far short of specifying precise prices. Instead, it establishes a series of 'common principles'178 that govern 'the essential features of airport charges and the way they are set'. ${ }^{179}$ Beyond these, the Directive is notably permissive in terms of the procedure or methodology to be followed, 180 whether charges are set initially by airport operator or public regulator, ${ }^{181}$ and the actual level of fees at any airport. ${ }^{182}$ The primary objective is to regulate the relationship between airport management authorities and users (i.e. airlines), and specifically, to prevent abuse of market power by the former. ${ }^{183}$ Yet, pursuit of this goal requires neither centralisation nor full harmonisation: it is sufficient simply to guide domestic price-setting through a series of EU law obligations that are nonnegotiable, but hardly unduly onerous. ${ }^{184}$

Finally, a 'peculiar'185 form of supervision is contained in the so-called Transparency Directive, ${ }^{186}$ which regulates domestic price-setting for medicinal products. Such price controls must accommodate several often-conflicting policy considerations: securing a consistent supply of necessary medicines; minimising expenditure of finite public resources; and protecting private incentives for research and innovation; all within a market where the lucrative 'artificial competition' 187 of parallel trade is vigorously protected yet of dubious social value. Against this background, the Directive acknowledges the prima facie legitimacy of regulation, whether imposed directly through price controls, or indirectly through purchasing activity of national health systems. It nonetheless seeks to constrain the discretion of Member States-and thus minimise potential obstacles to free movement-by imposing procedural requirements, including time-limits and a duty to give reasons. As Deutsche Parkinson ably illustrates, these comparatively high-level obligations have proven insufficient to avoid (perceived) market distortions. Yet the failure of efforts to strengthen and update Directive

\footnotetext{
176 Directive 2009/12/EC of 11 March 2009 on airport charges (OJ L 70/11, 14.3.2009) ("Airport Charges Directive').

177 Ibid, Recital (2).

178 Ibid, Article 1(1).

179 Ibid, Recital (2).

180 See e.g. recitals (2), (15) and (17); confirmed in Commission v Luxembourg, para.70

181 The Directive explicitly preserves the right of Member States to apply 'additional regulatory measures' such as direct regulation of charges, provided these comply with EU law-but, crucially, does not mandate such an approach: see Article 1(5), Airport Charges Directive.

182 As Advocate General Mengozzi argued in his Opinion in Commission v Luxembourg EU:C:2010:776, para.87, different national circumstances, such as labour costs, mean that quite different fee levels may be appropriate across the EU even taking into account the common principles.

183 Confirmed in Commission v Luxembourg, para. 42.

184 A conclusion confirmed, in effect, in Commission v Luxembourg.

185 Language taken from the Commission's website describing the Directive, available at https:/ / ec.europa.eu/growth/sectors/healthcare/competitiveness/products-pricingreimbursement/transparency-directive en (accessed 4 January 2017).

186 Council Directive 89/105/EEC of 21 December 1988 relating to the transparency of measures regulating the prices of medicinal products for human use and their inclusion in the scope of national health insurance systems (OJ L40/8, 11.2.1989) ('Transparency Directive').

187 Case T-168/01 GlaxoSmithKline EU:T:2006:265, para.146.
} 
89/105/EEC, 188 due to 'no foreseeable agreement' among legislators, ${ }^{189}$ demonstrates the national sensitivities and divergent vested interests at play.

Taken together, these examples illustrate both the overarching logic of the permissive approach and the extent to which the details of each regime depend upon the market dynamics at issue. By structuring national decision-making processes for price regulation, whether by limiting the circumstances in which controls are permissible or by mandating the procedure to be followed, in each instance the EU-level supervisory framework limits, but does not remove completely, national discretion. Consistent with the principles of subsidiarity and proportionality, both of which prioritise the 'least restrictive alternative' in the replacement of domestic with EU-level control, these examples are concerned with setting 'rules of the game,' but not prejudging actual results. Recurrent use is made of what are essentially principles of good governance-including timeliness, ${ }^{190}$ transparency, ${ }^{191}$ non-discrimination, ${ }^{192}$ consultation, ${ }^{193}$ objectivity, ${ }^{194}$ and verifiability ${ }^{195}$ — which bind and thus constrain Member States when engaging in price regulation. This structural approach, on the one hand, seeks to influence but not predetermine the substantive scope of any domestic controls; on the other, it serves to pry open often opaque and perhaps murky domestic processes to greater scrutiny, at both national and EU levels. ${ }^{196}$ Each of the examples discussed above, moreover, involve duties to inform the Commission of measures to implement the required decision-making framework and/or of specific decisions taken under it. ${ }^{197}$ These obligations serve a twofold purpose: both to condition and further constrain domestic policymaking insofar as it takes place, overtly, in the so-called 'shadow of hierarchy'; and to provide early warning to the Commission of inadequate domestic structures or, more problematically, distortive controls.

The underlying objective is to depoliticise price regulation, in effect turning it into a largely technocratic enterprise in these areas. By constraining the discretion of Member States and throwing light on regulatory processes and outcomes, EU law seeks to limit the extent to which domestic regulation might favour vested

\footnotetext{
188 Proposal for a Directive of the European Parliament and of the Council relating to the transparency of measures regulating the prices of medicinal products for human use and their inclusion in the scope of public health insurance systems (COM/2012/084 final), published 1 March 2012.

189 See Annex to the Commission Work Programme 2015 (COM(2014)910 final), published 16.12.2014, p.10. The Proposal was formally withdrawn in OJ C 80/17, 7.3.2015.

190 Article 7, Access Directive; Article 6, Airport Charges Directive; Articles 2-5 \& 7, Transparency Directive.

191 Articles 13(4) \& 15, Access Directive; Articles 3-5 \& 7, Airport Charges Directive; Article 3, Electricity Directive; Articles 2-5, Transparency Directive.

192 Article 3, Airport Charges Directive; Article 3, Electricity Directive;

193 Article 6, Framework Directive; Article 6, Airport Charges Directive; Articles 37(2), Electricity Directive.

194 Article 3, Airport Charges Directive; Article 2(2), Transparency Directive; Article 8(4), Access

Directive.

195 Article 2(2), Transparency Directive.

196 As de Witte (2013), 1573, writes in a related context, 'the objective...is not to challenge or re-orient the content of a national policy ... but rather to rationalise its implementation, and to ensure the absence of discrimination or protectionism.'

197 Article 3(10), Electricity Directive; Article 11(3), Airport Charges Directive; Article 8(5), Access Directive; Articles 2-3 \& 6-8, Transparency Directive.
} 
private or public interests at the expense of the wider competition process within the internal market. The permissive approach thus shares with the public choice movement a certain scepticism regarding the inherent unreliability of regulators, but not, it would seem, the regulatory enterprise more generally. Implicit here is a suspicion that, left to their own devices, national regulators are likely to favour domestic over Union interests, or social over economic ones. Yet the answer is not, as public choice would have it, to abandon or prohibit price regulation entirely as a doomed exercise. Instead, EU law seeks the more constructive path of channelling domestic regulators towards better policymaking, with due regard, amongst other things, for competition implications.

This is illustrated most clearly by an increasing use of rigorously independent authorities at national level to implement and administer supervisory requirements originating in EU law. Both the electricity and telecommunications frameworks, for instance, require the existence of legally distinct and functionally independent national regulatory authorities (NRAs). ${ }^{198}$ In each case, the NRA is required to exercise its regulatory powers impartially and transparently; ${ }^{199}$ this includes a prohibition on seeking or taking instruction from other bodies, including public or governmental entities, ${ }^{200}$ while the Electricity Directive demands independence from 'any market interest'. ${ }^{201}$ Such requirements are intended to increase both the authority of domestic regulators and the predictability of their decisions, in order 'to remove any reasonable doubt as to the neutrality of that body and its imperviousness to external factors'. ${ }^{202}$ Implicit here is the assumption that exposure to such factors would somehow diminish the effectiveness of domestic regulatory activity, coupled with a strong conviction of the relative efficiency of bureaucratic regulation in contradistinction to political decision-making. The Airport Charges Directive similarly requires establishment of 'national independent supervisory authorities,' legally and functionally independent from stakeholders, to mediate in the event of failure to reach agreement on charges. ${ }^{203}$ More radically, one proposed innovation within the (now failed) revisions of the Transparency Directive was the requirement for a designated body, independent from whichever public agency engages in price regulation at national level, to impose monetary penalties against defaulting Member States where domestic regulators fail to comply with time-limits. 204

The permissive approach emphatically does not give carte blanche to Member States, however. An intrinsic corollary of the constrained discretion permitted is that, if exceeded when imposing price controls, the errant Member State stands in violation of EU law. That is, the mere fact that the EU legal framework envisages the possibility of regulation does not equal a presumption

198 Article 3(2), Framework Directive and Article 35(4)(a), Electricity Directive.

199 Article 3(3), Framework Directive and Article 35(4), Electricity Directive.

200 Article 3(3)(a), Framework Directive and Article 35(4)(b)(ii), Electricity Directive.

201 Article 35(4)(b) (i), Electricity Directive.

202 Case C-424/15 Ormaetxea Garai EU:C:2016:780, paras.45-46. Although this case dealt with the recast Framework Directive, the almost identical provisions in the Electricity Directive suggest that such reasoning is equally applicable.

203 Article 11, Airport Charges Directive.

${ }^{204}$ See fn.188, draft Article 8. 
that any domestic controls are acceptable. The energy sector illustrates this tension. As we have seen, EU law does not merely contemplate price regulation in the electricity and gas sectors, but indeed requires a degree of supervision in certain instances. Following its energy sector inquiry, the Commission was nonetheless strongly critical of regulated retail tariffs, which it argued could have 'highly distortive effects and ... pre-empt the creation of liberalised markets. ${ }^{205}$ In Federutility, the Court of Justice split the difference by confirming the continuing power of Member States to imposed retail price controls in liberalised gas markets, while articulating demanding requirements, both in procedural and substantive terms, to be satisfied where Member States exercise that power. ${ }^{206}$ The latter proved a stumbling block in Commission v Poland, where, regardless of whether market circumstances merited some degree of intervention, the price controls at issue - unlimited in time, and applicable without distinction to all consumersrepresented a disproportionate incursion into liberalised gas markets in Poland. ${ }^{207}$ Prices determined by the interplay of supply and demand thus remain the preferred option and final objective within liberalised markets. ${ }^{208}$ Ultimately, even when EU law adopts a more permissive approach to price regulation in the first instance, domestic controls may prove incompatible with the internal market.

\section{DIRECT PRICE REGULATION: THE PRESCRIPTIVE APPROACH}

Thus far, we have considered indirect means by which 'potential obstacles to trade arising from national price control measures can be prevented': under both approaches discussed above, EU law has an essentially proscriptive, or negative, function, that is, 'imposing limits on national regulations on prices'. ${ }^{209}$ 'This section instead considers more direct or interventionist means by which EU law might seek to control pricing, namely, 'by regulating prices at [Union] level.'210 Such regulation is 'exceptional,' justified only in 'unique' circumstances; 211 two recent examples of such extraordinary activity will be considered, exploring the rationales for and broader implications of this approach.

The prohibitive approach considered in section IV is an essentially polarised one: the EU prerogative of developing and protecting market competition pitched against Member State interests in restricting a vital competitive parameter. The more permissive approach seen in section $\mathrm{V}$ is a largely cooperative one: the EU and Member States collaborate to devise and implement price controls that strike

\footnotetext{
205 European Commission, DG Competition Report on Energy Sector Inquiry (SEC(2006) 1724), published 10 January 2007, para.1047.

206 Case C-265/08 Federutility and Others v Autorità per l'energia elettrica e il gas EU:C:2009:640; the continuing applicability of this approach to the Third Energy Package is confirmed in ANODE, para.35.

207 Case C-36/14 Commission v Poland EU:C:2015:570.

208 ANODE, para.26.

209 Opinion in Vodafone, para.15.

210 Ibid, para. 15.

211 See Vodafone, para.67, where the Court endorsed the approach in recital (13) of the Roaming Regulation.
} 
an appropriate balance 'between the free market and regulation, between competition and the implications of the general interest'. ${ }^{212}$ Such cooperation breaks down only where the Member State exceeds the terms of its limited permission granted by the EU supervisory framework. At their core, however, both are reflective of the inherent ideological challenge of price regulation within ostensibly free markets: the former is unavoidably viewed as a deviation from the archetype of the latter. Moreover, both presuppose a dichotomy between EU law-as a centralising, neutralising force, on course towards ever greater competition - and national laws-as a source of divergence and distortion.

Our third approach complicates this picture by addressing-highly atypicalinstances in which EU law is itself a vehicle for harmonised price controls implemented directly within domestic markets. The exceptional nature of such activity reveals the complexity of accommodating price regulation within both the ideological and institutional structure of the EU, considered in section III. The overt commitment to open and undistorted competition pervades the conventional responses to market dysfunction under the EU legal framework: namely, to reinforce existing competitive dynamics - whether by structural reform, removing regulatory restraints that inhibit competition, or through antitrust enforcement against private actors-as opposed to overstepping those market forces entirely through prescriptive regulation. ${ }^{213}$ To the extent that EU law makes provision for price regulation, typically it does so through the conduit of domestic processes, aligned towards a Union archetype. This 'intermediate' approach—of requiring Member States to both facilitate and monitor competition, but not of prejudging the outcome of the competitive process-fits with the EU's own intermediate status, situated at a further remove from national markets and economic actors than Member State governments. It moreover reflects, arguably, the most appropriate allocation of 'proper political accountability' between the EU and Member States, ${ }^{214}$ given the plurality of 'legitimate regulatory goals' that might be pursued alongside the overarching objective of market integration. ${ }^{215}$

Despite these potential objections, EU law can — and very occasionally hasembraced more prescriptive regulatory intervention through specific ex ante price controls: devised and imposed at EU level, taking effect within national markets, and applying directly to the activities of private actors. Two examples are considered: the Roaming and Interchange Fee Regulations. Both were enacted under Article 114 TFEU, which enables harmonisation in furtherance of the internal market, involving the Commission, Council and Parliament in the legislative process. In both instances, the control mechanism takes the form of a price ceiling, albeit set at levels where the potential for competition below the regulatory maximum may be more theoretical than real. Domestic regulators, moreover, have little or no ability to deviate from the EU-wide maximum. Indeed, an express rationale for intervention, in each instance, was the perceived

\footnotetext{
212 Opinion in Federutility, para.53.

213 An approach seen, for instance, in the outcomes of both the Commission's energy and pharmaceutical sector inquiries: see European Commission, Pharmaceutical Sector Inquiry. Final Report, published 8 July 2008, and fn.205 above.

214 Opinion in Vodafone, para.1.

215 Ibid, para. 9.
} 
inadequacy of national regulation, due to the competitive distortions that might arise from domestic divergences. ${ }^{216}$

As the preceding sections discussed, however, the mere existence of divergent domestic price regulation is not prohibited by EU law; the prohibitions of the free movement provisions remain applicable where such regulation actually distorts competition within the internal market; and, where domestic regulation is viewed as likely or necessary, an overlay of EU supervisory law is arguably the orthodox option. Bearing in mind the logic of the subsidiarity principle, these examples thus raise questions as to when and why such exceptional EU-level regulation is warranted. To address these, it is necessary to understand and compare the objectives behind and regulatory circumstances of both Regulations. While our sample size is unavoidably small due to the relative absence of such legislation, it is possible to discern various recurring themes which may serve to explain the precedence granted to EU-level action here.

The first example is the Roaming Regulation, which sets EU-wide prices for mobile roaming services. 'Roaming' occurs when mobile customers use their phones abroad. To supply coverage, home providers must, correspondingly, purchase wholesale network access within the host Member State. Historically, rates for wholesale access were high, reflected in equally inflated retail prices. Identified as a dysfunctional market following a Commission sector inquiry, ${ }^{217}$ the issue was initially pursued through antitrust enforcement and 'soft' law efforts. ${ }^{218}$ When these failed to generate reductions in rates, ${ }^{219}$ the Commission chose a more distinctly 'regulatory' solution: an EU-wide maximum for wholesale access, plus a limitation on the permissible retail mark-up to $130 \%$ of wholesale prices. 220 This sought to address the 'core problem' that prices for roaming stood 'in no meaningful relationship to the underlying costs, ${ }^{221}$ resulting in 'unjustifiably high' charges. ${ }^{222}$ Entering in force in June 2007223 and initially covering only voice calls, it had been extended to text messages ${ }^{224}$ and internet data, while costs were

\footnotetext{
216 An argument accepted by the Court of Justice in the context of the Roaming Regulation in Vodafone, para.47, and subsequently spelled out in recitals (12) and (13) of the Interchange Fee Regulation.

${ }^{217}$ European Commission, Working Document on the Initial Findings of the Sector Inquiry into Mobile Roaming Charges, published 13 December 2000.

218 See European Commission Press Releases IP/05/901, "Commission warns consumers on cost of using mobile phone abroad and targets lack of price transparency," published 11 July 2005; IP/05/1217, "Commission launches consumer website on the costs of mobile roaming in Europe," published 4 October 2005; and IP/04/1458, "Commissioner Reding welcomes EU-wide investigation on cost of using a mobile phone abroad," published 10 December 2004.

219 Commission Staff Working Paper, Impact Assessment of Policy Options in Relation to a Commission Proposal for a Regulation of the European Parliament and of the Council on Roaming on Public Mobile Networks within the Community (COM(2006)382 final), published 12 July 2006, 12-13.

${ }^{220}$ European Commission, Proposal for a Regulation of the European Parliament and of the Council on roaming on public mobile networks within the Community and amending Directive 2002/21/EC on a common regulatory framework. for electronic communications networks and services (COM(2006)382 final), published 12 July 2006.

221 Ibid, 17.

$222 \mathrm{Ibid}, 22$

${ }^{223}$ Roaming Regulation.

${ }^{224}$ Regulation 544/2009 of 18 June 2009 amending Regulation 717/2007 on roaming on public mobile telephone networks within the Community and Directive 2002/21/EC on a common regulatory framework for electronic communications networks and services (OJ L167/12, 29.6.2009).
} 
reduced progressively. 225 The EU institutions are working towards the abolition of roaming surcharges entirely, to take effect from June 2017.226

Our second example concerns interchange fees for payment cards. Interchanges fees comprise the costs levied by card system operators to merchants that accept payment, and have long been subject to public criticism and regulatory scrutiny. 227 These concerns were reflected in the Commission's sector inquiry into retail banking, which identified, inter alia, large variations in fees across Member States alongside generally high levels.228 Initially, antitrust enforcement was considered sufficient to address these problems; eventually, the Commission opted for a more comprehensive approach with a specific Regulation on fee-setting. ${ }^{229}$ The core function of the Interchange Fee Regulation is to cap maximum permissible fees for consumer credit and debit card transactions involving fourparty payment card schemes, such as Visa and MasterCard. ${ }^{230}$ In devising fee levels, the Commission took account of both economic theory and existing administrative practice; 231 the Regulation thus sets maximum fees of $0.2 \%$ for consumer debit card transactions and $0.3 \%$ for consumer credit card transactions. ${ }^{232}$ It also establishes various 'business rules' applicable to card-based payments. ${ }^{233}$ The key pricing provisions took effect from December 2015.

Despite the clear factual differences, several elements unite these distinct examples, which may explain the regulatory priority granted within EU law. It is at this juncture that the threefold factors that influence the overarching approach to price regulation can be seen most clearly, whether occurring at the domestic or Union levels: namely, the competition policy implications, the social policy considerations, and the link to broader market integration.

First, both markets had been subject to considerable scrutiny within the broader framework of the EU's competition policy powers prior to enactment of the relevant Regulations. This suggests the pre-existence of significant market dysfunction within these sectors; circumstances that were, moreover, a source of substantial EU-level concern. Commission sector inquiries, appropriate where 'the trend of trade between Member States, the rigidity of prices or other

${ }^{225}$ Regulation 531/2012 of 13 June 2012 on roaming on public mobile communications networks within the Union (OJ L172/10, 30.6.2012).

226 Regulation (EU) 2015/2120 of 25 November 2015 laying down measures concerning open internet access and amending Directive 2002/22/EC on universal service and users' rights relating to electronic communications networks and services and Regulation (EU) No 531/2012 on roaming on public mobile communications networks within the Union (OJ L 310/1, 26.11.2015).

${ }^{227}$ Discussing regulatory efforts within the EU, see Malaguti \& Guerrieri, Multilateral Interchange Fees: Competition and regulation in light of recent legislative developments, European Credit Research Institute Research Report No.14, published January 2014, 17-18. Considering efforts elsewhere, see Semeraro, "Credit Card Interchange Fees: Three Decades of Antitrust Uncertainty," 14 George Mason Law Review 941 (2007). ${ }_{228}$ Communication from the Commission, Sector Inquiry under Article 17 of Regulation (EC) No 1/2003 on retail banking (Final Report) (COM(2007)33 final), published 31 January 2007.

${ }^{229}$ European Commission, Proposal for a Regulation of the European Parliament and of the Council on interchange fees for card-based payment transactions (COM(2013)550 final), published 24 July 2013.

230 Regulation (EU) 2015/751 of 29 April 2015 on interchange fees for card-based payment transactions

(OJ L 123/1, 19.5.2015) ('Interchange Fee Regulation'), particularly Article 1.

${ }^{231} \operatorname{COM}(2013) 550,8$.

232 Articles 3 \& 4, Interchange Fee Regulation. For domestic transactions, Member States may impose lower caps if desired.

${ }^{233}$ Chapter III, Interchange Fee Regulation. 
circumstances suggest that competition may be restricted or distorted, ${ }^{234}$ had previously been carried out in each, illustrating the importance of these markets within the context of the internal market. Both inquiries revealed, amongst other dysfunctions, a risk of high pricing resulting from excessive market power. ${ }^{235}$ In each sector, this prompted competition enforcement, pursuing largely the same behaviour from an antitrust standpoint. ${ }^{236}$ Yet the subsequent decisions to regulate point to the intrinsic limitations of regulation through antitrust enforcement-or, instead, demonstrate the value-added of ex ante price controls in the face of persistent market power.

In the case of roaming, competition law proved largely incapable of addressing the exploitative oligopolistic behaviour at issue, meaning that regulation became necessary to secure an effective outcome. Although investigations were pursued against network operators, alleging abuse of dominance through excessive wholesale pricing, ${ }^{237}$ such efforts suffered from deficiencies that rendered intervention potentially unviable: including difficulties in establishing dominance, alongside a demanding test for excessive pricing that created uncertainty as to whether the practices could be held abusive. ${ }^{238}$ The Commission alluded to the 'complexity' of enforcement, ${ }^{239}$ and, once the Roaming Regulation was adopted, it closed the on-going investigations without findings of breach. 240

Interchange fees, by contrast, involve horizontal price-fixing, and thus come readily within the ambit of Article 101 TFEU. Antitrust enforcement has included commitment decisions involving Visa, in which the Commission criticised, in essence, excessive prices arising from co-ordinated price-setting; ${ }^{241}$ alongside an infringement decision against MasterCard, which held that its interchange fees breached Article 101(1) TFEU, and could not be exempted under Article 101(3) TFEU. ${ }^{242}$ Despite these successes, the piecemeal and essentially individualised nature of the remedies implemented provided an inadequate response to the systemic market failure at issue. The Commission thus determined that a topdown regulatory approach was required in lieu of 'ad hoc'243 efforts.

\footnotetext{
234 Article 17(1), Council Regulation (EC) No 1/2003 of 16 December 2002 on the implementation of the rules on competition laid down in Articles 81 and 82 of the Treaty (OJ L 1/1, 4.1.2003). 235 See fn. 217 and 228 above.

236 Other activities within both sectors have also attracted antitrust scrutiny: see Cases T-328/03 O2 (Germany) GmbH \& Co. OHG v Commission EU:T:2006:116, and T-461/07 Visa Europe and Visa International Service v Commission EU:T:2011:181.

${ }^{237}$ Commission Press Releases IP/04/994, "Commission challenges UK international roaming rates," published 26 July 2004, and IP/05/161, "Commission challenges international roaming rates for mobile phones in Germany," published 10 February 2005.

${ }^{238}$ Discussed by Klotz, "The Application of EC Competition Law (Articles 81 and 82) in the

Telecommunications Sector," in Koenig, Bartosch, Braun \& Romes (eds.), EC Competition and Telecommunications Law, 2nd ed., Kluwer Law International BV, The Netherlands (2009), 132-33. ${ }^{239} \operatorname{COM}(2006) 382$, p.38.

${ }^{240}$ Commission Press Release IP/07/1113, "Commission closes proceedings against part roaming tariffs in the UK and Germany," published 18 July 2007.

${ }^{241}$ Commission Decisions of 8 December 2010 in Case COMP/39.398 - VISA MIF (OJ C 79/8, 12.3.2011) and 26 February 2014 in Case AT.39398-Visa MIF (OJ C 147/7, 16.5.2014).

${ }^{242}$ Commission Decision of 19 December 2007 in Cases COMP/34.579-MasterCard, COMP/36.518 EuroCommerce and COMP/38.580_Commercial Cards (summary at OJ C 264/8, 6.11.2009); upheld in Cases T-111/08 MasterCard EU:T:2012:260 and C-382/12 P MasterCard EU:C:2014:2201.

243 See Speech of Joaquin Almunia, "Introductory remarks on proposal for regulation on interchange fees for cards, Internet and mobile payments," (SPEECH/13/660), published 22 July 2013.
} 
Second, in each instance the rationale for regulation was not merely a desire to improve the efficient functioning of markets: both, additionally, reflect social and integration concerns. For the Roaming Regulation, consumer protection was a key impetus, as high costs were perceived as exploitative of non-business travellers in particular. ${ }^{244}$ Thus, the Commission called for 'a clear demonstration that Europe can act in the interest of citizens in a case where Member States are not equipped to act. ${ }^{245}$ In the context of the Interchange Fees Regulation, it was small and medium-sized merchants-who pay interchange fees in the first instance, and lack the economic clout to negotiate more favourable rates individually-that shouted loudest (and lobbied hardest) for EU-level intervention. In both cases, price regulation is therefore a means by which access to these increasingly important products can be secured, on realistic terms, primarily for the benefit of individuals and businesses without substantial market power. Significantly, in each instance the ostensible social concern has a pan-Union existence or identity, thus warranting recognition at EU level. This stands in contrast to the divergent social concerns that prompt price regulation at the national level, which, as discussed above, are granted a relatively circumscribed deference.

Additionally, both sectors involve a significant cross-border element, meaning that their effective functioning-including affordable access to key products/services - links to development of the internal market, thus providing a plausible rationale for the necessity and appropriateness of EU-level intervention. By its nature the levying of additional costs for use of mobile phones between Member States constitutes a barrier to integration and free movement: indeed, market segmentation is inherent to roaming as a service category. Moreover, the cross-border nature of these services was a central reason why national regulators were unable to address the problem. ${ }^{246}$ Although the internal market element is not intrinsic to payment cards, card systems are a central component of $e$ commerce infrastructure. A well-functioning integrated payment market is accordingly portrayed as vitally important, if not practically indispensable, to development of the internal market, ${ }^{247}$ again particularly from the perspective of ordinary consumers and smaller businesses. In both instances, therefore, the Commission grounded its subsidiarity analysis in the transnational nature of the market - and market failure-at issue. ${ }^{248}$ Notably, both roaming and the development of e-commerce markets are also central components of the Commission's wider — and wildly ambitious-'Digital Single Market' strategy. ${ }^{249}$

Article 114 TFEU accordingly provides the basis for both Regulations. Although granting wide-ranging legislative powers, Article 114 does not '[vest] in the [EU] legislature a general power to regulate the internal market'. ${ }^{250}$ Hence, it was necessary for the Commission to establish a 'disfavouring of cross-border

\footnotetext{
$244 \operatorname{COM}(2006) 382,19-20$

245 Ibid, 26.

246 Ibid, 17 \& 25-26.

247 See, e.g., Interchange Fee Regulation, recitals (6) and (9).

$248 \operatorname{COM}(2006) 382,7$, and $\operatorname{COM}(2013) 550,14$.

${ }^{249}$ Communication from the Commission, A Digital Single Market Strategy for Europe, COM(2015)192 final, published 6 May 2015

${ }^{250}$ Case C-376/98 Germany v Parliament and Council ('Tobacco Advertising') EU:C:2000:544, para.83.
} 
economic activity,' and not merely a hindrance of economic activity as such. ${ }^{251}$ Both Regulations thus proceed on the assumption that, absent EU-level regulation, disparate and potentially distortive national price controls were likely to arise. ${ }^{252}$ An interesting question, however, is whether the EU would have authority to legislate absent domestic divergence: that is, might the EU legislature intervene purely to address inefficient or otherwise socially undesirable price-setting by private actors at Member State level? Arguing tentatively in the affirmative in Vodafone, Advocate General Poaires Maduro drew parallels to Viking and Laval, which involved application of the free movement provisions to private parties due to 'the direct impact that private acts ... could have on free movement'. ${ }^{253}$ Where private economic activity involves a direct disfavouring of cross-border trade, he argued, the EU legislature should have capacity to regulate that behaviour. Where it involves wholly domestic trade, however-for instance, efforts to regulate the price of 'suitcases or restaurant meals' 254 - the necessary link to cross-border trade is lacking. In such circumstances, the task of price regulation, if necessary, should fall to Member States unless an alternative legislative basis exists. 255

It is worth comparing, finally, the differing scope of the two regimes. In one sense, the Roaming Regulation is more intensive and ambitious. It mandates wholesale- and retail-level controls, on the basis that wholesale regulation alone would not ensure that savings pass to consumers, while retail regulation without a reduction in costs might create a price squeeze. ${ }^{256}$ Moreover, the Commission's ultimate objective has been to eliminate roaming charges entirely, thus essentially rendering the service category obsolete (at least within 'fair use' parameters). The progressive reduction in rates might be viewed as akin to forcing the internal market, insofar as operators must price as if a single 28 country-wide market for mobile telephony services already exists; whereas, in reality, mobile markets remain segmented along national lines. The Interchange Fee Regulation is less farreaching in this sense. The Commission rejected a complete ban on interchange fees for debit cards on the basis that the market is insufficiently mature (or, that it had insufficient knowledge of its maturity) to recommend such an option at that stage. ${ }^{257}$ Additionally, the Commission rejected retail regulation of interchange fees, implicitly suggesting that this might intrude too far into private economic activity. ${ }^{258}$

Yet the ultimate reach and impact of the Interchange Fee Regulation may be much greater than that of the Roaming Regulation. The latter involves a deep incursion into commercial freedom, yet confined within narrow circumstances. The Interchange Fee Regulation, conversely, addresses a broader subject-matter-

\footnotetext{
251 Opinion in Vodafone, para.22 (emphasis added). On this point, see $\operatorname{COM}(2006) 382$, 6, and $\operatorname{COM}(2013) 550$ final, 3 .

252 See fn. 216.

253 Opinion in Vodafone, para.21.

254 Ibid, para. 22.

255 A possibility is the 'flexibility provision' under Article 352 TFEU, which provides a residual basis for legislation 'to attain one of the objectives set out in the Treaties' in the absence of 'the necessary powers,' but requires unanimity in the Council.

${ }^{256} \operatorname{COM}(2006) 382,6$.

257 Ibid, 13

258 Ibid, 12.
} 
payment card transactions-and governs fees for cross-border and domestic consumer card transactions. In practical terms, it thus represents a significant step beyond mere regulation in furtherance of specific EU objectives, and towards regulation of the functioning of national markets as such. ${ }^{259}$ This, in turn, suggests a further departure from the logic of subsidiarity, alongside a declining tolerance for domestic divergence or disparities. Central to both Regulations, however, is an implicit acknowledgement that the concept of effective competition within the internal market structure is considerably more complex than the language of 'free,' 'open' or 'undistorted' competition might suggest.260

\section{CONCLUSIONS}

[A] measure which requires a product or service to be offered on the market at a determined price ... is by its very nature contrary to the objective of achieving an open and competitive market. ${ }^{261}$

Yet the treatment of price regulation within EU law nonetheless accommodates many contrasting regulatory impetuses, which extend beyond the bare pursuit of competition as such. Within competition policy, there is friction between the default preference for unencumbered price-setting versus the pragmatic reality of sometimes-dysfunctional markets. In the realm of market integration, there are questions of whether and when price controls create distortions that ripple across the internal market, alongside tensions arising from delegation of price supervision to domestic regulators. Justifications for regulation often take us into the delicate territory of social policy, raising questions of how and to what extent noneconomic considerations can be addressed within the overtly competitive structure of the internal market; and whether the EU can and should challenge domestic regulatory preferences. As the above discussion illustrates, there is no single or simple answer in most instances.

At its core, price regulation remains an inherently domestic activity. EU law plays an essentially secondary role: whether proscribing problematic national regulation; guiding domestic regulatory processes; or even, exceptionally, overreaching an array of divergent Member State controls through EU-level price regulation. Challenging questions of both subsidiarity - when should EU law intervene-and proportionality - to what extent should EU law pre-empt domestic regulatory choices-abound. Two potential sources of concern with respect to domestic regulation implicitly pervade EU law. First, there is the issue of competence: whether domestic regulators have sufficient ability to design and implement

\footnotetext{
259 The validity of the Interchange Fee Regulation is the subject of an on-going reference procedure under Article 267 TFEU: Case C-304/16 American Express Co. (OJ L 123/1, 19.5.2015).

260 See, e.g. Recital (12) of the Roaming Regulation, which explicitly recognises the regime it establishes as a 'departure' from the competition-focus approached of telecommunications regulation generally, while the logic of the Interchange Fee Regulation is that the limitation of one dimension of economic freedom is necessary to promote greater competition in the longer term (see, particularly, Recital (9)). 261 ANODE, para.30.
} 
effective controls to minimise distortions within the otherwise open and competitive internal market. Second, there are issues of integrity and fidelity to the Union: can domestic regulators be trusted to work alongside and in furtherance of market integration and competition, or might they fall prey to capture by vested national interests, whether public or private. Underlying these concerns is the question of whether price regulation is a science or art. The former implies processes that can be structured, controlled and tested, alongside objectively 'correct' outcomes; the latter suggests a holistic or intangible exercise, involving value judgments, where the beauty may lie in the eye of the beholder. Yet, within the hierarchical structure of EU law, incompatible national controls must yield to EU-level intervention, whether proscriptive or prescriptive in nature.

The treatment of price regulation under EU law moreover hints at certain paradoxes that lie within the concept of a 'highly competitive social market economy'. Pricing and the price formation mechanism are central components of any system of open competition; yet free formation of prices cannot alone guarantee effective competition, nor it is indispensable to well-functioning markets in the broader sense. The social policy concerns and market conditions that underpin most regulation are typically national in origin and nature; yet the existence of multiple discrete and discordant price control structures is conceptually inapposite in moving towards an ostensible single market. Price regulation and its discontents within EU law thus reflect the inherent tensions and compromises that arise from an inevitable sharing of regulatory jurisdiction within the internal market, alongside the complications stemming from a plurality of legitimate yet opposing regulatory goals. Perhaps most fundamentally, it points to the intricate nature and equivocal benefits of the competition process: in a social market economy, the free functioning of the inimitable price formation mechanism is ostensibly paramount, yet not invariably optimal. Within the varying approaches to price regulation under EU law, we see principled attempts to reconcile and resolve these tensions between market and state, national and supranational. Hence, the most pragmatic response to the conundrum of price regulation within the social market economy may be by reference to Azoulai's 'model of reconciliation': to recognise that, although contradictions exist, these are partial, not total; with a concomitant effort to reconcile as far as possible the plurality of values - economic, social, and integrationist - existing within today's internal market. ${ }^{262}$ 'Open and undistorted competition' is thus both slogan and archetype, but not an unbending prescription as such.

262 Azoulai, "The Court of Justice and the Social Market Economy: The Emergence of an Ideal and the Conditions for its Realisation" 45 CMLRev 1335 (2008), 1346-49. 